Michal Bauer, Jana Cahlíková,

Dagmara Celik Katreniak, Julie Chytilová,

Lubomír Cingl, and Tomáš Želinský

\title{
Anti-social Behavior in Groups
}

Max Planck Institute for Tax Law and Public Finance

Working Paper 2018 - 14

November 2018

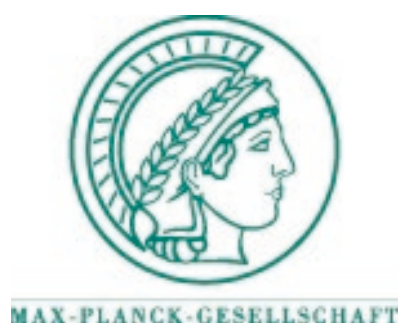

Max Planck Institute for

Tax Law and Public Finance

Department of Business and Tax Law

Department of Public Economics

http:/ / www.tax.mpg.de 
Working papers of the Max Planck Institute for Tax Law and Public Finance Research Paper Series serve to disseminate the research results of work in progress prior to publication to encourage the exchange of ideas and academic debate. Inclusion of a paper in the Research Paper Series does not constitute publication and should not limit publication in any other venue. The preprints published by the Max Planck Institute for Tax Law and Public Finance represent the views of the respective author(s) and not of the Institute as a whole. Copyright remains with the author(s).

Max Planck Institute for Tax Law and Public Finance

Marstallplatz 1

D-80539 Munich

Tel: $\quad+498924246-0$

Fax: $\quad+498924246-501$

E-mail: ssrn@tax.mpg.de

http://www.tax.mpg.de 


\title{
Anti-social Behavior in Groups
}

\author{
Michal Bauer, Jana Cahlíková, Dagmara Celik Katreniak, \\ Julie Chytilová, Lubomír Cingl, and Tomáš Želinský
}

\begin{abstract}
This paper provides strong evidence supporting the long-standing speculation that decision-making in groups has a dark side, by magnifying the prevalence of anti-social behavior towards outsiders. A large-scale experiment implemented in Slovakia and Uganda $(\mathrm{N}=2,309)$ reveals that deciding in a group with randomly assigned peers increases the prevalence of anti-social behavior that reduces everyone's payoff but which improves the relative position of own group. The effects are driven by the influence of a group context on individual behavior, rather than by group deliberation. The observed patterns are strikingly similar on both continents.
\end{abstract}

Keywords: antisocial behavior, aggressive competitiveness, group membership, group decision-making, group conflict

JEL: C92, C93, D01, D64, D74, D91

\footnotetext{
* Bauer: CERGE-EI (a joint workplace of Charles University and the Economics Institute of the Czech Academy of Sciences), Politických vězňů 7, 11121 Prague 1, Czech Republic, and Institute of Economic Studies, Faculty of Social Sciences, Charles University (e-mail: bauer@ cerge-ei.cz). Cahlíková: Max Planck Institute for Tax Law and Public Finance, Marstallplatz 1, 80539 Munich, Germany, and CERGE-EI (e-mail: jana.cahlikova@tax.mpg.de). Celik Katreniak: National Research University, Higher School of Economics, Shabolovka 26, 119049 Moscow, Russia, and CERGE-EI (e-mail: dcelik@hse.ru). Chytilová: Institute of Economic Studies, Faculty of Social Sciences, Charles University, Opletalova 26, 110 00 Prague 1, Czech Republic, and CERGE-EI (e-mail: chytilova@fsv.cuni.cz). Cingl: Faculty of Economics, University of Economics in Prague, nám. W. Churchilla 4, 13067 Praha 3, Czech Republic (e-mail: lubomir.cingl@vse.cz). Želinský: Faculty of Economics, Technical University of Košice, Němcovej 32, 04022 Košice, Slovakia, and Institute of Economic Studies, Faculty of Social Sciences, Charles University (e-mail: tomas.zelinsky@tuke.sk). The data collections were funded by the Czech Science Foundation (P402/12/G130, Slovakia and 13-20217S, Uganda). Further support was provided by the Czech Science Foundation (Bauer and Chytilová, 17-13869S) and by the H2020-MSCA-RISE project GEMCLIME-2020 GA No. 681228 (Bauer and Chytilová). We thank Gary Charness, Stefano DellaVigna, Dirk Engelmann, Armin Falk, Uri Gneezy, Shachar Kariv, Supreet Kaur, Martin Kocher, Filip Matějka, Jan Zápal, and participants at various seminars and workshops for helpful comments and conversations. We also thank Maria Bedlovičová, Michal Gul'aš, Gabriel Markovič, Viktor Mrážik, Lucia Šolcová, Ramjet Banura, Yaseen Nsubuga, Winifred Candiru, Remmy Nambowa, and Isma Nyombi for excellent research assistance in the field.
} 


\section{INTRODUCTION}

Since writings about the limits of democracy by Plato (trans. 1891) and later by the founding fathers of the American constitution, social scientists have been worried about the effects of being a part of a group and the dynamics of group decision-making, speculating that these may exacerbate motivations to harm outsiders and destroy overall social welfare. ${ }^{1}$ Recognizing that many political, military, and business decisions are made by groups of people rather than by individuals acting in isolation, the study of the causal effect of decision-making in groups has become a prominent research agenda in behavioral economics during the last two decades (Camerer 2003). A stylized pattern has emerged across many laboratory experiments that compare choices of groups and individuals: groups behave less pro-socially than individuals do - they are less willing to sacrifice their own resources to increase social welfare or to achieve fair allocation of payoffs. ${ }^{2}$

A prevailing interpretation of this robust pattern is that groups behave in a more selfregarding way, meaning that groups are more prone to maximize a group payoff and disregard the welfare of others - see incisive recent surveys by Charness and Sutter (2012) and Kugler, Kausel, and Kocher (2012). The behavioral difference is typically attributed to communication among group members, helping to recognize a dominant strategy. This interpretation has powerful implications for economic theory. It suggests that group decisions can be modeled as more rational and less "behavioral" than individual decisions and that "game theory based on standard assumptions may be, after all, a much better descriptive theory than currently believed." (Kugler, Kausel, and Kocher 2012). Charness and Sutter (2012) summarize the emerging consensus as follows: "The bottom line emerging from economic research on group decision-making is that groups are more likely to make

\footnotetext{
1 In Plato's opinion, democracy involves rule by irrational mobs and for this reason he favored the rule of an enlightened individual (Allport 1968). Alexander Hamilton, James Madison, and John Jay - the first two being members of the Constitutional Convention - shared a similar concern: "In all very numerous assemblies, of whatever character composed, passion never fails to wrest the scepter from reason. Had every Athenian citizen been a Socrates, every Athenian assembly would still have been a mob." (Publius 1948, p. 248). Also, in his seminal work on crowd psychology (Le Bon 1895, p. 35) argues: "Isolated he may be a cultivated individual; in a crowd he is a barbarian-that is, a creature acting by instinct." In line with this concern, societies that are fragmented into pre-existing groups were found to be more prone to political instability and violent inter-group conflicts (Easterly and Levine 1997; Alesina and La Ferrara 2005; Olsson and Siba 2013).

2

2 Most of this literature is based on the comparison of choices made by individuals and unitary teams/groups (typically composed of three members), in which group members have to make a joint team decision. Psychologists have extensively studied behavior in the Prisoners' Dilemma game and nearly all of their studies show that groups defect more often than individuals, a pattern denoted as "discontinuity effect," (see Wildschut et al. 2003 for a meta-study on group effects in the Prisoners' Dilemma games). Less pro-social behavior among groups as compared to individuals has also been observed in the Dictator game (Luhan, Kocher, and Sutter 2009), Ultimatum game (Robert and Carnevale 1997; Bornstein and Yaniv 1998), or Trust game (Song 2008; Cox 2002; Kugler et al. 2007), although two exceptions to this pattern exist (Cason and Mui 1997; Balafoutas et al. 2014).
} 
choices that follow standard game-theoretic predictions, while individuals are more likely to be influenced by biases, cognitive limitations, and social consideration."

In this paper, we implement a large-scale lab-in-field experiment on two continents, and provide new evidence showing that the behavioral difference in inter-personal interactions between individuals and groups is primarily driven by groups being more anti-social, and less so by a greater prevalence of self-regarding behavior. Anti-social behavior refers to non-strategic destructive behavior that is costly for the decision maker, reduces welfare of others, and is not a response to inequality or a hostile behavior of a counterpart. It can be motivated by either pure spitefulness (preference to minimize payoff of others) or aggressive competitiveness (preference to maximize relative payoff). ${ }^{3}$ Furthermore, the more prevalent anti-social behavior in group decisions arises almost exclusively due to the effects of group context, rather than due to deliberation among group members. Therefore, our findings provide direct support for a long-standing hypothesis from social psychology that simply being a member of a salient group may affect individual behavior and give rise to anti-social actions towards outsiders (Durlauf 1999; Hewstone, Rubin, and Willis 2002; Sumner 1906; Sambanis, Schulhofer-Wohl, and Shayo 2012), and thus intensifies a dark side of human social motivations.

These distinctions matter because they are essential for being able to predict a willingness to engage in self-destructive conflict. First, being anti-social is a substantial step from being selfregarding: While economic agents motivated purely by self-interest are predicted to destroy resources of others only when there are pecuniary benefits to be gained, the scope for harming others is magnified dramatically if economic agents derive utility from relative status or feel pleasure from beating an opponent. Second, if the mere fact of deciding in a group context changes individual willingness to cause harm to an outgroup - rather than group decision-making involving group discussion, persuasion or aggregation of individual preferences - then the findings are relevant for a broader range of situations since they do not depend on the existence of deliberation among group members.

\footnotetext{
3 In contrast, self-regarding behavior refers to choices that maximize own payoff and disregard the payoffs of others. Finally, we will refer to behavior as pro-social when decision makers choose to sacrifice their own payoff in order to increase total welfare or achieve fair allocation of rewards, in the absence of strategic motives.
} 
To shed light on these questions, the experimental design in this paper contains three novel elements. The experimental tasks employed in previous work, including the Prisoners' Dilemma game, Trust game, and Dictator game, are designed to measure the extent of the positive side of human social behavior. Thus, these tasks are mute when it comes to the question as to whether a lack of willingness to cooperate or share with others is due to a greater selfishness vs. anti-social behaivor. ${ }^{4}$ In this paper, we also conduct the Prisoner's Dilemma game (PDG), which has been used most frequently to study group decision-making in psychology and economics, with the aim ro replicate previous findings. Importantly, we also elicit choices in the Joy of Destruction mini-game (JDG). In JDG, in contrast to PDG, destroying social welfare is costly for the decision maker and thus the dominant strategy for purely self-regarding individuals is not to engage in destructive behavior. This task helps us to tease apart whether groups destroy more due to greater self-interest, in line with economic textbook assumptions, or due to anti-social motivations. Second, in order to separately identify the effects of group context on individual decisions and the effect of group communication and joint decisionmaking, we elicit individual choices made in isolation, preferences of individual group members for group decisions before a group deliberation, and the ultimate group decisions. The third distinguishing feature is that we conducted the experiments among unusually large and diverse samples of subjects who were not drawn from a self-selected population of university students, and we test the robustness of the findings in two very distinct countries using a comparable design. Specifically, the study is based on an experiment implemented among more than two thousand adolescents from 34 schools in rural Uganda ( $\mathrm{N}=1679)$ and 13 schools in disadvantaged regions in Eastern Slovakia $(\mathrm{N}=630)$.

We present three main findings. First, we show that groups, as compared to individuals, are less likely to cooperate in the Prisoner's Dilemma game, in line with findings in previous experiments. Importantly, groups are also more likely to harm opponents in the Joy of Destruction game in which

\footnotetext{
4 Several studies have documented that anti-social behavior is quite common in many societies (Falk, Fehr, and Fischbacher 2005; Herrmann, Thoni, and Gachter 2008; Prediger, Vollan, and Herrman 2014; Goette et al. 2012; Abbink and Herrmann 2011), but little is known about the role of group membership or group decision-making. An initial step in this direction is in Balafoutas et al. (2014) who employ a set of allocation tasks among students of University of Innsbruck which allow them to identify spiteful behavior. In the setting they study, the authors do not find groups to be less pro-social than individuals. At the same time, crime and other forms of anti-social behavior were found to be much more common among individuals with low socioeconomic status (Lochner and Moretti 2004; Deming 2011), suggesting that to study anti-social behavior, it might be necessary to go beyond the standard lab sample of university students (sometimes referred to as WEIRD - Western, educated, and from industrialized, rich, and democratic countries). Thus, here we focus on subjects from disadvantaged regions from two continents.
} 
the dominant strategy for self-regarding agents is not to engage in destructive behavior, since destruction is costly for decision makers (Abbink and Herrmann 2011; Abbink and Sadrieh 2009). An analysis that combines choices from the two tasks reveals the difference in willingness to destroy the resources of others is primarily due to a greater prevalence of anti-social behavior and, to a lesser extent, due to a greater prevalence of self-regarding behavior among groups.

Second, we find that the stronger anti-social behavior of groups as compared to individuals is driven by elevated aggressive competitiveness and that it cannot be explained by differences in beliefs, reciprocal motives, inequality aversion or diffusion of individual responsibility. Groups are more willing than individuals to pay to cause harm even when they respond to a kind act of an experimental counterpart and when destroying resources increases inequality, and thus in a decision situation, in which neither beliefs, reciprocal motives nor inequality aversion could motivate destruction. Furthermore, we find that anti-social behavior in a group setting is elevated simultaneously with willingness to enter competition with outsiders, as measured in the competitiveness game (Niederle and Vesterlund 2007). Together, these findings indicate that the two behavioral responses have a common origin and support the interpretation that individuals in groups are more aggressively competitive, i.e. that group environment magnifies the pleasure of beating an opponent, even if that implies harming others and sacrificing own resources.

Third, we decompose the overall group effects and find that both the group context as well as deliberation among group members matter. The effect of group context elevates individual willingness to engage in anti-social behavior, as well as individual willingness to compete, whereas the group decision-making stage somewhat increases prevalence of self-regarding choices. Last, all the observed effects are strikingly similar across the Ugandan and Slovak samples.

Our results contribute to the experimental literature on group decision-making (Bornstein and Yaniv 1998; Kugler et al. 2007; Kugler, Kausel, and Kocher 2012; Charness and Sutter 2012) by demonstrating that the behavior of groups in interactive settings is more complex than purely an outcome of less "behavioral" choices than those of individuals. While we find support for a shift towards self-regarding behavior due to group deliberation, the main driver of the difference between 
individual and group behavior is the effect of deciding in a group context, which makes group decisions as compared to individual decisions more anti-social, i.e. more behavioral but in a dark sense.

Methodologically, our paper contributes to efforts aiming to uncover the mechanisms behind the systematic group effects on decision making with more detailed measurement. Recently, researchers started to study aggregation of preferences in groups by jointly eliciting individual preferences prior to the group deliberation stage as well as the ultimate group decisions (Balafoutas et al. 2014; Ambrus, Greiner, and Pathak 2015). Here we use an integrated design that allows studying both the process of aggregation of individual preferences in groups as well as the effects of group context within the same sample, and thus gauging potential quantitative and qualitative differences in impacts of these two mechanisms. Our effort to bridge the gap between the literatures on group membership effects (Charness, Rigotti, and Rustichini 2007) and group decision-making in the domain of inter-personal behavior is inspired by Sutter (2009) who introduced this approach in the domain of decision making under uncertainty.

Our results also speak to the literature on group membership and parochial altruism. Recent gene-cultural evolutionary models provide an explanation why parochial altruistic preferences - a form of group-based preferences which motivate people to behave pro-socially towards the in-group members and anti-socially against outsiders - are likely to emerge and persist (Fehr and Fischbacher 2003; Choi and Bowles 2007; Bowles 2008). The idea is that societies composed of a greater number of parochial altruists are predicted to succeed in the environment of inter-group competition which characterized much of human history (Bowles 2009; Keeley 1997). Many experiments have demonstrated that group membership increases pro-social behavior towards in-group members, relative to out-group members, and that salience of group membership may influence the magnitude of the in-group bias in the extent of pro-social behavior (Bernhard, Fischbacher, and Fehr 2006; Goette, Huffman, and Meier 2006; Chen and Li 2009; Alexander and Christia 2011; Charness, Rigotti, and Rustichini 2007). As highlighted in Sambanis, Schulhofer-Wohl, and Shayo (2012), while the evidence of in-group favoritism is relatively rich, the evidence on anti-social aspects of parochialism is 
still scant. Goette et al. (2012) find that cues of competition between groups trigger hostility towards out-group members in the form of anti-social punishment. We contribute to the literature by focusing on unambiguously anti-social behavior and demonstrating that salient group context alone increases preference for aggressively competitive behavior towards out-siders. Since we find similar effects across very diverse economic and cultural environments, the results suggest that the observed dark side of group membership has deep and generalizable underpinnings.

The paper proceeds as follows. Section 2 describes the samples, experimental tasks, and manipulations, and it provides brief background information about the two field sites. Section 3 presents the results, and Section 4 concludes.

\section{EXPERIMENTAL DESIGN}

\subsection{Sample selection}

The experiments are implemented in two very different settings. We study the behavior of participants from the Slovak Republic - an OECD and European Union member country with 2015 GDP per capita in PPP at \$29,931 - and rural Uganda, a developing country in sub-Saharan Africa with 2015 GDP per capita in PPP at $\$ 1,851$. The data collection took place during June-October 2013. The experiments were conducted at schools, a setting which allows us to compare individual decisions with the decisions of groups composed of real-life peers who live in a similar social environment and who regularly interact with one another.

The Slovak sample consists of 630 adolescents from 13 schools located in villages and small towns scattered across the Eastern part of the country (see Panel A of Figure A.1). We sampled from a population aged 13-15 (grade 8 and 9, i.e. the last two grades of primary school). Since schooling in Slovakia is obligatory until the age of 16 and there are very few selective tracks prior to this age, organizing the experiments among the last grades in primary schools helps us to avoid problems that could arise due to self-selection into the experiment. Since the region is characterized by a high proportion of the Roma ethnic minority population (15\%), the setting also allows us to study the role of social distance by manipulating the identity of the experimental counterpart - Slovak or Roma. Of 
the subjects, $95 \%$ are from the majority Slovak ethnic group and 5\% are members of the Roma minority. All were sampled from schools attended predominantly by majority Slovak students, but located within five kilometers of a Roma minority neighborhood or settlement.

The Ugandan sample consists of 1,679 adolescents. We sampled 24 primary schools and 10 secondary schools located in the rural areas of Buikwe and Mukono districts, about 30-100 kilometers from the capital city Kampala. The schools are scattered across the districts (see Panel B of Figure A.1). ${ }^{5}$ The subjects are adolescents attending the last grade of primary school and the two final grades of lower-secondary school. Grade repetitions are quite common, resulting in substantial age variation within each school grade. In our sample $92 \%$ of the P7 students are aged $12-15$ and $91 \%$ of S3 and S4 students are aged 15-18. Primary schooling in Uganda has been free and compulsory since 1997 and the initiative was expanded to secondary schools in 2007 (although hidden fees still exist). Only around $6 \%$ of primary-school-age and $21 \%$ of lower-secondary-school-age children were out of school as of 2013 and 2010, respectively.

Participation in the experiment was voluntary and the subjects could leave at any time. ${ }^{6}$ Virtually all students decided to complete the tasks. Sample characteristics are presented in Table A.1. To illustrate the diversity of our sample, Slovak subjects live in standard developed-country housing, $98 \%$ of the families own a TV, and $89 \%$ own a car. Slovak subjects have on average two siblings and almost everybody's parents have a secondary or a tertiary degree. The Ugandan subjects typically live in housing with no electricity in $62 \%$ of the cases, $16 \%$ of the households own a car, families are much larger with seven siblings on average, and $34 \%$ of mothers and $25 \%$ of fathers have only a primary school degree or no education.

\footnotetext{
5 These schools represent a sub-set of schools in which follow-up data on a large-scale education randomized control trial (RCT) has been collected. The RCT took place one year before the data collection and examined the effects of feedback and incentives on test scores in mathematics, English, and happiness (for details, see Katreniak Celik (2016)). The results presented in this paper are robust to controlling for the RCT treatments and hold for the control group that had not received any intervention (available upon request).

We obtained approval to conduct the experiments from the Director of Institute of Economic Studies at the Faculty of Social Sciences, Charles University in Prague, from the Dean of the Technical University of Košice, and from the headmasters of participating schools. The research was also officially supported by the Buikwe District Local Government in Uganda.
} 


\subsection{Experimental tasks}

Subjects in both countries made choices in two complementary tasks, which allow us to identify prosocial, self-regarding, and anti-social behavioral types - the Prisoner's Dilemma game and the Joy of Destruction game. In Uganda, subjects also participated in an additional task designed to measure their willingness to compete (Competitiveness game). The order of the tasks was randomized across schools and the results are robust to controlling for order effects. The experimental design shares the same core elements in both countries, nevertheless it differs in several specific aspects motivated by our effort to address additional questions, as we detail below. Table A.2 provides a comparison of the design features across the two countries. The full experimental protocol is available upon request.

In order to measure the willingness to cooperate, we administered a Prisoner's Dilemma game (PDG). In this game, two players receive the same endowment and simultaneously decide whether to take away $50 \%$ of their counterpart's payoff in order to increase their own payoff by $25 \%$ (defection/non-cooperative choice) or whether to keep the payoffs unchanged (cooperative choice). Defection is a dominant strategy for a purely self-regarding player, but the socially optimal outcome is reached when both players cooperate. In Slovakia, the subjects were endowed with EUR 1.60 and could increase their payoff by 40 cents by taking away 80 cents from the counterpart. In Uganda, the endowment was Ush 800 and the subjects could increase their payoff by Ush 200 by taking away Ush 400 from the counterpart. ${ }^{7}$

In order to identify anti-social behavior we administered a money-burning game, which we will refer to as the Joy of Destruction game or JDG (Abbink and Herrmann 2011; Abbink and Sadrieh 2009). Two players receive the same endowment and simultaneously decide whether to pay $10 \%$ of their endowment in order to decrease the counterpart's payoff by $50 \%$ (destructive choice) or whether to keep the payoffs unchanged (non-destructive choice). In this case, destructive choices lead to outcomes far below the social optimum. Importantly, the dominant strategy of a purely self-regarding player is not to engage in destructive behavior, as s/he would have to pay for it. Sequential fairness

\footnotetext{
7 For EUR 2, a subject in Slovakia could buy two soft drinks, three notebooks, two pens and a highlighter, or five candy bars. For Ush 1000, a subject in Uganda could buy three or four exercise books, one quarter of a grilled chicken, or three chapattis (a local salty pancake). At the time of the experiment, the exchange rate was approximately 3,400 Ush/EUR.
} 
motives, such as reciprocity, cannot justify destruction either, since choices were made simultaneously without knowing what the counterpart did. In principle, it can be motivated by either anti-social preferences (spitefulness or aggressive competitiveness) or by beliefs about the likelihood of destructive behavior by the counterpart combined with negative reciprocal preferences. In the following text we will denote the choice to reduce the other's payoff in JDG as hostile or destructive. In Slovakia, the subjects were endowed with EUR 2 and could pay 20 cents to reduce a counterpart's payoff by EUR 1. In Uganda, the endowment was Ush 1000 and the subjects could pay Ush 100 to reduce counterpart's payoff by Ush 500 .

Payoff matrices of the two games as administered in Slovakia and Uganda are presented in Figure 1. We used neutral framing for both games. ${ }^{8}$ The combination of choices in PDG and JDG allows us to classify subjects into the following mutually exclusive behavioral types: self-regarding (maximizing their own pay-off), anti-social (minimizing the other's pay-off), and pro-social (maximizing the other's pay-off).

In each game, participants were first asked to make an unconditional decision, i.e. choose an action without knowing what the other player did. Subsequently, the participants were also asked to state their beliefs about the decision of their anonymous counterpart and to make two conditional decisions - for the situation when their counterpart decided to keep the payoffs unchanged, and for the situation when their counterpart decided to lower the decision maker's payoff.

In Uganda, we also implemented a Competitiveness game (CG) following the approach of Niederle and Vesterlund (2007). Participants performed a real effort task, namely solving mazes for five minutes. First, they performed the task under a piece-rate compensation - Ush 150 for each correctly solved maze. Second, they performed the same type of task under a competitive tournament scheme - for each correctly solved maze, they received Ush 450 if they performed better than a randomly selected counterpart, Ush 150 if they performed equally well, and nothing if they performed worse. Third, without receiving any feedback on their performance in the first two rounds, the

\footnotetext{
8 For example, in Slovakia, the question was "Do you want to take 80 cents from the other person/group to get 40 cents for yourself?" (PDG) and "Do you want to pay 20 cents and reduce the other person's/group's income by 1 euro?” (JDG).
} 
participants performed the same task again and could choose whether they would be paid under the piece-rate compensation or the tournament scheme. This choice provides us with a measure of willingness to compete. If subjects entered the competition, their performance in the third round was compared to the counterpart's performance in the second round. This approach has several advantages. The performance of those who enter the tournament is evaluated against the performance of participants who also performed under the tournament compensation scheme. Also, while beliefs about their own relative performance in a tournament may affect the choice to enter the competition, beliefs regarding the choices of others cannot. Finally, there are no externalities associated with the entry to competition because participants' choices in the third round do not affect anybody else's payoff. Last, after all three rounds, to measure confidence we asked subjects whether they believed that in the second round they performed better, equally, or worse than their counterpart.

The subjects were paid for a subset of randomly selected decisions. In Slovakia, one decision out of six (one unconditional choice and two conditional choices in PDG and in JDG) in each of two conditions in which we manipulated the ethnicity of the experimental counterpart (see the next subsection for the description of these conditions) was relevant for payment. In Uganda, subjects were paid for one decision out of three in JDG (one unconditional choice and two conditional choices), for one decision out of three in PDG, and for performance in one of the three rounds in CG. ${ }^{9}$ Beliefs about actions of counterpart were in both countries elicited using hypothetical questions.

\subsection{Experimental manipulations}

We randomly manipulated "between-subjects" whether the participants were making choices individually or in groups. In the INDIVIDUAL condition, subjects were making choices in isolation, without being observed by classmates and with no information regarding their classmates' choices. In the GROUP condition, subjects were randomly allocated into groups of three. They were matched with actual peers from their class, with whom they regularly interact. When making choices, they sat

\footnotetext{
9 Note that such incentivization differs from the usual practice in experimental economics of paying subjects for only one randomly selected decision, in order to avoid hedging across choices. We have decided to pay subjects for more than one choice in order to increase the salience of receiving rewards and thus keeping high levels of attention throughout the experiment among this relatively young subject pool.
} 
next to each other around one desk (Slovakia) or on one mat (Uganda) and were informed they had up to four minutes of free discussion to reach a joint decision.

Subjects in the INDIVIDUAL condition were matched against an individual counterpart, while in the GROUP condition every group was matched against another group of three individuals. It was specified that the payoffs described in the experimental instructions were per member and that each member of the group would receive the same payoff. Thus, the individual payoffs were identical across the INDIVIDUAL and GROUP conditions. In addition, in order to be able to distinguish whether potential differences between GROUP as compared to INDIVIDUAL conditions are due to the fact that decision making takes place in groups or due to the fact that the experimental counterpart is a group, in Slovakia we implemented two versions of the GROUP condition: a condition in which groups interacted with groups (GROUP_GROUP), and a condition in which groups interacted with individuals (GROUP_IND). Since we find similar patterns in GROUP_GROUP and GROUP_IND, in the main analysis we pool observations from these two conditions and later discuss the robustness.

In order to identify the effect of deciding in a group on individual willingness to engage in destructive choices and in order to study how individual preferences are aggregated into an ultimate group decision, subjects in the GROUP condition were asked to state their individual preference regarding the group unconditional decision (IND_IN_GROUP), prior to group deliberation stage. In all tasks, individuals indicated how they preferred the group to decide. Importantly, to minimize the extent to which these individual preferences are affected by opinions of other members of the group, these individual preferences were elicited in private, i.e. individual decisions could not be observed by the other two group members, and they were made prior to the stage when group members were allowed to communicate about the task. Further, in the main experiment we have decided to rely on hypothetical questions when eliciting this preference so that subjects did not need to be concerned about the other group members being able to infer their choices from the information about final payments. At the same time, to test whether we arrive at similar patterns with incentivized measure, in Slovakia we implemented "between subjects" an additional condition (IND_ON_BEHALF). Specifically, subjects made decisions individually on behalf of their group as dictators, and these 
decisions were payoff relevant with one-third probability for the subject as well as for two randomly matched peers who observed the subject's choices. ${ }^{10}$ Since the individuals are deciding as dictators, the diffusion of responsibility cannot affect their choices, which might be the case when subjects make decisions as a whole group. We will show below that findings are very similar when using the hypothetical and the incentivized question.

The counterparts in the games were always anonymous. In Uganda, the counterpart came from the same school as the participant. In Slovakia, the subjects knew that the counterparts came from an unspecified school in the same region. Further, in order to test whether social distance between decision makers and counterparts increases the magnitude of group effects, we manipulated whether the counterparts were of the majority ethnicity (i.e. the same as the decision maker), or whether the counterparts came from the Roma ethnic minority. ${ }^{11}$ These two conditions were implemented "withinsubject", in a random order. We pool observations from these two conditions in the main analysis and later discuss the robustness.

After the experimental tasks, we collected data about observable characteristics of participants and their family background. Most of these characteristics vary little across the experimental conditions, indicating that randomization was successful (Table A.1).

\subsection{Procedures}

After a general introduction, the students randomly picked an ID number, which determined into which of the two conditions (INDIVIDUAL, GROUP) they were allocated and, in the latter condition, with whom they were matched. The condition and matched peers remained the same for all decisions.

We took several steps to ensure that choices in INDIVIDUAL and IND_IN_GROUP were fully anonymous and choices in GROUP were observed only by the members of the group. Subjects submitted all answers under their experimental IDs. The experimenter who explained the tasks to the

\footnotetext{
10 In a separate paper Bauer et al. (2018) we study how choices of subjects in IND_ON_BEHALF influence choices of the other two matched peers who made their own choices afterwards, in order to estimate the level of contagion of hostility.

11 Ethnicity was signaled using a list of 20 real names of potential counterparts (ten male and ten female names), where the list contained either typical Slovak names, or typical Roma names.
} 
subjects could not observe the decisions made as all answer sheets and questionnaires were submitted privately into a box located in the corner of the classroom (Slovakia) or collected by assistants (Uganda). The answer sheets were processed and payments were later administered by a different person. Further, subjects were assured that the experimenters would not share information about decisions and resulting earnings with other participants, teachers, or parents.

Experimental payoffs were denoted in real money. In Uganda, subjects obtained their earnings in cash at the end of the experiment, augmented by a show-up fee of Ush 100. Since in Slovakia headmasters requested not to use monetary rewards, subjects received rewards in the form of credit to order items from an experimental store, which contained 48 items ranging from sweets, snacks, and drinks to stationery, stickers, and bracelets, to satisfy a variety of tastes. All items were priced using retail prices. Prior to the experiments participants were provided with a "store catalog" in order to learn about items (depicted with pictures) and prices. After the experiments, they selected their preferred items, which were later distributed to schools in sealed bags marked with the participant's experimental IDs.

Experimental instructions were provided by five experimenters in Slovakia and two experimenters in Uganda who were randomly allocated to conditions in each school. The results are robust to controlling for experimenter fixed effects. To avoid communication about experimental tasks prior to participating, all subjects from each class participated in the experiment at the same time and all sessions within each school were implemented in a single day. Each session lasted around 1.5 hours.

The instructions were given in a local language, Slovak in Slovakia and Luganda in Uganda. ${ }^{12}$ To ensure understanding the tasks were explained in detail, using visual aids to illustrate options and payoffs. Before making choices in JDG and PDG, participants were asked four control questions about the payoff consequences of their actions and their counterpart's actions. As described below, the level

\footnotetext{
12 The instructions were translated into the local languages from the original English protocol. Translation to Slovak was performed by one of the co-authors who is a native speaker. Translation and back-translation to Luganda was done by two different professional translators. Final adjustments were agreed upon with the two experimenters responsible for explaining the instructions, who were fluent in English and Luganda.
} 
of understanding was high and the results are robust to excluding observations with imperfect understanding.

\section{RESULTS}

\subsection{Are Groups More Self-Regarding or Anti-Social than Individuals?}

We start by exploring whether groups are more socially destructive when such action is in their selfinterest. In the Prisoner's Dilemma game, defection reduces social welfare, but it is a dominant strategy for a purely self-interested agent. Overall, we find that groups are 19 percentage points more likely to defect as compared to individuals ( $\mathrm{p}<0.01$, Column 2 of Table 2). In Slovakia, subjects in the INDIVIDUAL condition defect in $67 \%$ of cases, while GROUP decisions lead to defection in $82 \%$ of cases (p-value $<0.01$, Table 1 and Figure 2). In Uganda, subjects in INDIVIDUAL choose to defect in $57 \%$ of cases, compared to $79 \%$ in the GROUP condition ( $\mathrm{p}$-value $<0.01$ ). Therefore, in both samples we study we replicate the stylized fact from the literature that groups defect more often than individuals in the Prisoner's Dilemma game.

Next, we explore whether groups are more destructive even when such action is costly for everyone. We employ the Joy of Destruction game, which allows distinguishing between selfregarding and anti-social motivations because the dominant strategy for self-regarding agents is not to engage in destructive behavior towards the counterpart, since destruction comes at a cost to the self/group. We find that a non-negligible proportion of subjects in the INDIVIDUAL condition choose to destroy in JDG. Still, the proportion of destructive choices is significantly larger in GROUP as compared to INDIVIDUAL condition $(\mathrm{p}<0.01$, Column 1 of Table 2$)$. The prevalence of destructive choices in INDIVIDUAL and GROUP conditions are $32 \%$ vs. $42 \%$ in Slovakia, and $53 \%$ vs. $59 \%$ in Uganda, and the difference is statistically significant in both countries $(\mathrm{p}=0.02$ and $\mathrm{p}=0.05$, respectively, Table 1). In other words, in both countries groups in JDG are significantly less likely to play the Nash equilibrium consistent with self-regarding preferences, as compared to individuals.

The observed levels of destruction rates are high, even in the INDIVIDUAL condition, but comparable to previous work. Existing money-burning games have focused on individual decisions 
and have documented destruction rates of $8-40 \%$ among university students in the Netherlands (Abbink and Sadrieh 2009), 10-26\% among university students in Ukraine (Abbink and Herrmann 2011), and 5-21\% among the university students in the USA (Kranton et al. 2017). Moving beyond the population of university students, Prediger, Volland and Herrmann (2011) observe destruction rates of 23\%-40\% among pastoralists in Namibia and show that levels of destruction are higher among the sub-sample experiencing stronger real-life scarcity of resources. Other types of anti-social behavior, such as the anti-social punishment of cooperators in the public good game, are also widespread and show large variation across countries. (Herrmann, Thoni, and Gachter 2008) document anti-social punishment to vary between $5-38 \%$ across 16 societies. Among adults in India, it reaches $61-73 \%$ (Hoff, Kshetramade, and Fehr 2011). Overall, the prevalence of anti-social behaviour seems stronger among individuals from disadvantaged regions as compared to university students, which is also consistent with our results. Also, as we discuss below, we find that subjects in our sample have relatively accurate beliefs about prevalence of destructive behaviour and that high levels of destruction are not driven by subjects with imperfect understanding of the task.

Next, we combine both choices in JDG and PDG and classify subjects into four mutually exclusive behavioral types. Subjects are classified as Self-regarding if they maximize their own payoff by harming others in PDG but choosing the non-destructive strategy in JDG; Anti-social if they harm others in both games; Pro-social if they cooperate in PDG and do not destroy in JDG; and Ambiguous if they cooperate in PDG and destroy in JDG. Tables 1 and 2 report the results.

As compared to individuals, groups are significantly more likely to behave anti-socially and the group effects are large in magnitude, representing approximately 50\% increase relative to the INDIVIDUAL condition. In Slovakia, $35 \%$ of groups behave anti-socially, compared to $23 \%$ in the INDIVIDUAL condition (p-value<0.01). In Uganda, the respective shares are $54 \%$ in the GROUP condition and 39\% in INDIVIDUAL ( $\mathrm{p}<0.01$ ). Groups are also more likely to behave in a purely selfregarding way as compared to individuals, although the effect is smaller in magnitude (4 p.p. in Slovakia and 8 p.p. in Uganda) and statistically significant only for the Ugandan sample $(\mathrm{p}<0.01$, Column 4 of Table 2). The increase in the prevalence of anti-social and self-regarding behavior among 
groups is mainly because groups are less likely to behave pro-socially: the difference is 13-14 percentage points in both countries and is statistically significant at the $1 \%$ level. In the Ugandan sample, it is also due to lower share of ambiguous subjects in GROUP as compared to INDIVIDUAL $(6 \%$ vs. $13 \%)$.

Observation 1: Groups are more likely than individuals to destroy resources of others, both when such action benefits the group as well as when it is costly for the group. The difference is mainly due to a greater prevalence of anti-social behavioral types.

We now report a series of robustness checks of the main finding. First, we test whether the reported effects are not due to differences in understanding between individuals and groups. Although groups have a higher probability of answering all control questions correctly than individuals ${ }^{13}$, the results hold when controlling for the level of understanding, as well as restricting the sample to observations with perfect understanding (Columns 1-4 in Table A.3). Also, given that most of the effects are driven by a change in individual behavior associated with deciding in a group context rather than due to deliberation among group members, as we show below, it is unlikely that the observed effects are due to differences in understanding. Second, we show that the patterns are not driven by particular design features or by specific schools and school grades in our sample. The results are robust to controlling for the order of the games, experimenter, school, and school-grade fixed effects (Table A.3). ${ }^{14}$

\subsection{Beliefs about the Anti-social Behavior of the Counterpart}

In this subsection, we analyze beliefs and conditional decisions, which were elicited immediately after each unconditional decision. The aim is to understand which type of anti-social motivations is

\footnotetext{
13 In Slovakia, all comprehension questions were answered correctly by $90 \%$ of groups and $77 \%$ of individuals in PDG and by $92 \%$ of groups and $84 \%$ of individuals in JDG. In Uganda, the comprehension questions in GROUP condition were answered separately by each member of group, prior to group deliberation. In PDG, all comprehension questions were answered correctly by at least one group member in $92 \%$ of groups, and by $73 \%$ of individuals. The corresponding numbers are $93 \%$ and $74 \%$ in JDG. 14

Our results also indicate that social distance between the decision maker and an anonymous experimental counterpart has little influence on whether subjects become more destructive in groups. In Slovakia, the counterparts came from an unspecified school in the same region, and thus were completely unknown to the decision makers. In addition, we manipulated whether the counterparts were from the same (majority) or different (Roma) ethnic group. The findings are qualitatively similar across the ethnicity of the counterpart (Table A.4). In Uganda, the counterparts were classmates, i.e. individuals whom the decision makers knew for several years. Even in this case, the decision makers become more anti-social when matched in groups.
} 
intensified in GROUP as compared to INDIVIDUAL. Note that in the unconditional decisions in PDG and JDG analyzed above, subjects decide without knowing the action of the experimental counterpart. Thus, the observed group effects on greater willingness to destroy can be driven either by anti-social preferences (spitefulness or aggressive competitiveness), or by differences in beliefs - if groups are more afraid of their counterparts and therefore want to protect themselves against the possibility of ending up like a loser.

We find no systematic differences in beliefs about a counterpart's behavior (Columns 3 and 6 , Panel A of Table 3). In JDG, we find virtually no differences across GROUP and INDIVIDUAL conditions in the prevalence of beliefs that an experimental counterpart will choose a destructive strategy. This (non-)result holds in pooled estimates (p-value=0.73) as well as when analyzing beliefs in each country separately ( $\mathrm{p}=0.94$ for Slovakia, $\mathrm{p}=0.62$ for Uganda, Panels B and C). In PDG, we find no statistically significant differences in beliefs about a counterpart's cooperativeness in Uganda ( $\mathrm{p}=0.50$ ). In Slovakia, groups expect counterparts to be somewhat less cooperative, but the difference is only marginally statistically significant ( $\mathrm{p}$-value $=0.08$ ). The group effects on choices in JDG and PDG are virtually unchanged when controlling for beliefs (Table A.5). Also, an interaction effect between beliefs about counterpart's behavior and GROUP condition on destructive choices is not significant statistically (Column 3 and 6 in Table A.5), indicating that beliefs do not play a larger role in decisions in GROUP as compared to INDIVIDUAL condition. Note however that as beliefs are potentially endogenous, these results should be treated cautiously.

It is noteworthy that beliefs in the JDG are relatively accurate. Goups in Slovakia expect destruction in $42 \%$ of the cases, which is equal to the actual destruction rate. In Uganda, groups predict destruction in $62 \%$ of the cases and the actual destruction rate is $59 \%$. Individuals in both countries predict more destruction in JDG than the actual destruction rates (43\% vs. $32 \%$ in Slovakia and $60 \%$ vs. 53\% in Uganda). For PDG, groups expect somewhat less defection than the actual noncooperation rates (73\% vs. $82 \%$ in Slovakia and $68 \%$ vs. $79 \%$ in Uganda), individuals in Slovakia are on point (66\% non-cooperative beliefs vs. $67 \%$ actual defection) and individuals in Uganda expect more defection than the actual rates (66\% vs. $57 \%)$. 
Further, to the extent to which players are sensitive to the nature of the counterpart, and expect groups and individuals to behave differently, they should choose different behavioral strategies depending on whether they face a group or an individual. Thus, in Slovakia, we compare choices of groups which interact with groups (GROUP_GROUP) and groups which interact with individuals (GROUP_IND). This manipulation provides a complementary test - based on incentivized actions rather than directly elicited but hypothetical beliefs - of whether fear of more destructive behavior when a counterpart is a group is driving the behavioral difference between groups and individuals. We arrive to the same conclusion, as in the analysis of beliefs (Table A.6). The choices and beliefs are similar in GROUP_IND and GROUP_GROUP conditions, while the prevalence of destructive choices is larger in the GROUP_IND condition, as compared to the INDIVIDUAL condition.

Observation 2: Groups do not expect to be harmed more often than individuals and do not condition their behavior depending on whether the counterpart is a group or an individual, suggesting that greater destructiveness of groups is not driven by differences in beliefs about the behavior of counterparts.

Next, we study conditional decisions, in which beliefs should not play a role, and find that groups still behave systematically more destructively than individuals (Panel A of Table 3). As compared to individuals, groups have a systematically stronger preference for defection in conditional decisions in PDG. This result holds for both countries (Panels B and C) and independently on whether the counterpart was cooperative or not. In JDG, groups are more destructive than individuals when responding to the non-hostile behavior of the counterpart (p-value $=0.02$ both for Slovakia and Uganda). We do not find a significant difference between GROUP and INDIVIDUAL in the prevalence of destructive choices when responding to a destructive action of the counterpart for Slovakia $(\mathrm{p}=0.34)$ and only a marginally significant result for Uganda $(\mathrm{p}=0.09) .{ }^{15}$

\footnotetext{
15 We also use all four conditional choices (two in PDG and two in JDG) to classify subjects into four behavioral types: self-regarding (always maximizing their own payoff), anti-social (always reducing other's payoff), pro-social (always maximizing other's payoff), and conditionally cooperative (always choosing the same action as the counterpart). The remaining combinations of choices are classified as "other". Reassuringly, we observe broadly similar patterns as when analyzing differences in the prevalence of behavioral types based on unconditional choices. Decision making in groups, as compared to individual decision-making, increases the prevalence of anti-social behavior (mainly in Uganda) and self-regarding behavior (mainly in Slovakia), and reduces the prevalence of pro-social and conditionally cooperative behavior (Table A.7)
} 
Observation 3: Groups are more willing to pay to harm counterparts even if responding to a kind action of an experimental counterpart, suggesting that decision making in groups elevates the willingness to engage in anti-social behavior towards people outside of one's own group.

The analysis suggests that differences in beliefs (fear of being harmed) are unlikely to explain the more destructive behavior of groups, as compared to individuals. It is also noteworthy that the group effects are not specific for choices, in which decision makers respond to the unkind behavior of a counterpart (non-cooperative strategy in PDG and destructive strategy in JDG). If anything, the opposite seems to be the case. The difference in behavior between groups and individuals is particularly systematic when decision makers make a choice after an experimental counterpart acted kindly. Thus, the observed increase in destructive inclinations of groups cannot be attributed to a greater preference to retaliate, and suggests that either a greater aggressive competitiveness (defined as a preference to maximize relative payoff) or pure spitefulness (preferences to minimize payoff of others) motivates groups to destroy more. We revisit this question in Section 3.4. where we explore data from the Competitiveness game employed among the Ugandan sample to tease out whether antisocial behavior is driven by competitive or spiteful preferences.

\subsection{Decomposing the Group Effects: Deciding in a Group Context vs. Group Deliberation}

In this sub-section, we decompose the overall group effects on behavior into two parts. First, in order to identify the effects deciding in a group context, we compare individual choices made in isolation (INDIVIDUAL) with preferences of individual group members on how subjects want their group to decide (IND_IN_GROUP). Second, in order to estimate the effects of group communication and deliberation, we take advantage of having both preferences of individual group members for group decision (IND_IN_GROUP) and actual group choices (GROUP), and analyze how individual preferences aggregate into group decisions. Here we will mostly focus on the extent to which group choices depart from an outcome implied by majority-voting principle, since an application of this principle may mechanically lead to different choices of individuals and groups. Note that this analysis will be based on unconditional decisions only since we elicited individual preferences for group 
decisions only for unconditional decisions (and not for beliefs and conditional decisions), i.e. before groups started to deliberate about a given task.

The social context of deciding in a group has an important influence on individual choices in both games. In JDG, the prevalence of destructive choices in IND_IN_GROUP is significantly larger than in INDIVIDUAL (Panel A of Table 4). At the same time, the prevalence of destructive choices in the IND_IN_GROUP condition is almost identical to the prevalence of destructive choices made by groups after the deliberation and aggregation of individual preferences in GROUP (Panel B). We find the same qualitative patterns in both the Slovak and the Ugandan samples. Thus, the overall group effect on a greater prevalence of destructive behavior that is costly for the group can be fully attributed to the effects of deciding in a group context, rather than the effect of group deliberation.

In PDG, we find that the individual preferences for the group decision are located almost exactly between the choices made by individuals in isolation and the group choices. Deciding in a group context increases the likelihood of defection by ten percentage points (Panel A). An additional nine percentage-point increase is due to the effect of the group decision-making process (Panel B). Again, these effects are strikingly similar in both countries. Thus, we conclude that the effect of deciding in a group context explains roughly half of the overall group effects on the likelihood of defection, while the remaining half is due to the group deliberation.

In Slovakia we implemented additional condition (IND_ON_BEHALF), in which individuals were deciding as dictators on behalf of the whole group. Choices in this condition were incentivized and could not be affected by diffusion of responsibility. We arrive at a similar pattern as when using responses in the IND_IN_GROUP condition: The prevalence of destructive choices in JDG is significantly larger when individuals were deciding as dictators on behalf of a group as compared to when they decided in isolation ( $45 \%$ vs. $32 \%, \mathrm{p}=0.01$, Chi-square test). In PDG, the difference in the prevalence of defection between INDIVIDUAL and IND_ON_BEHALF is not statistically significant (67\% vs. $72 \%, \mathrm{p}=0.36)$ and is of smaller magnitude than the difference between INDIVIDUAL and IND_IN_GROUP $(67 \%$ vs. $75 \%, p=0.01)$. 
Observation 4: Individual willingness to behave anti-socially is elevated when individuals make choices in a group context, as compared to choices made in isolation: Group members choose to destroy resources of others more often, both when such action benefits the group as well as when it is costly for the group.

In Table 5, we explore in more detail the process of aggregation of individual preferences in groups. In particular, we study how the composition of preferences among group members affects a collective group decision. In PDG, 91\% of groups in which a majority of group members (two or three) prefers the group to defect follow the average initial judgment. Thus, only $9 \%$ of groups do not behave according to an average initial judgment and decide to cooperate. In a situation when all group members unanimously prefer to defect, groups choose to cooperate in only $5 \%$ of cases. In contrast, the group decision-making process matters more when the majority of group members enter the group decision-making stage with the initial preference to cooperate - the ultimate choice is to cooperate only in $51 \%$ of cases. In the remaining $49 \%$ of cases, groups do not follow the outcome implied by the average initial judgment and the group decision-making process substantially increases the prevalence of defection in this game. Even among groups in which all group members initially want the group to cooperate, group deliberation results in choosing defection in $38 \%$ of cases. This asymmetry holds in both countries and illuminates why group deliberation increases the prevalence of defection in PDG.

At the same time, we do not observe a similar asymmetry in the likelihood of departing from behavior implied by majority-voting principle in JDG. From groups in which the majority of members prefer to destroy ex-ante, $77 \%$ end up destroying. From groups in which the majority prefers not to destroy, $79 \%$ end up choosing not to destroy. This symmetry helps to explain why we find virtually no effect of group deliberation on the prevalence of destructive behavior, in contrast to the effect of deciding in a group context, as observed in group-members' decisions prior to the group decisionmaking stage.

Observation 5: Group deliberation increases the prevalence of defection in PDG, in which harmful behavior increases group payoff, but it does not reduce the prevalence of destruction in JDG, in which harmful behavior is costly for the group. 
Together, the findings favor the interpretation that the effect of deciding in a group context is the major source of the behavioral differences between groups and individuals, especially the tendency to be destructive even at their own costs. The findings suggest that individuals value a shared experience of winning and beating an opponent. Alternatively, deciding in a group context could also lead to diffusion of responsibility, which could cause anti-social behavior to be more prevalent. However, given that we also find increased destruction in the IND_ON_BEHALF condition (where a dictator decides on behalf of the group and therefore cannot avoid the responsibility), we favor the first explanation.

At the same time, our results clearly show that the group decision-making process, such as the increased information processing capabilities in groups (a higher potential to identify a dominant strategy or more thorough deliberation of expected behavior of a counterpart), or the dynamic that leads to the aggregation of individual preferences into a group decision (for instance, disproportionate ability of anti-social individuals to persuade others) do not seem to be major factors in elevating such anti-social tendencies. Group deliberation seems to increase the prevalence of destructive behavior that is beneficial for the group, but does not decrease the prevalence of destructive behavior which is costly for everyone.

\subsection{Aggressive Competitiveness in Groups}

So far, we have documented that making choices in a group context increases individual willingness to destroy resources, even at own cost and cost for the group. A possible explanation for such anti-social behavior is that individuals, when banded in groups, become more competitive, i.e. have a greater desire to win over an opponent, even if that implies sacrificing their own resources. To address this explanation more directly, in the Ugandan data collection (but not in Slovakia), we implemented a third task to measure competitive preferences - the Competitiveness game (CG). We test: (i) whether groups have a greater appetite to enter competition, and (ii) whether the willingness to engage in competition in CG and in anti-social behavior (in PDG and JDG) are elevated simultaneously when choices are made in groups. 
We find a large difference in the willingness to compete across GROUP and INDIVIDUAL conditions. As shown in Figure 3 and Table 6, groups are much more likely to choose competitive contract (56\% vs. $39 \%, \mathrm{p}<0.01)$. The effect is robust to controlling for confidence and performance (Columns 1 and 2 of Table 7). ${ }^{16}$ Strikingly, we find the group effect on greater willingness to compete to be driven by the effect of deciding in a group context, and not by the effect of group deliberation (Table 4, Column 7). The likelihood of preferring the competitive contract is 20 percentage points larger in the IND_IN_GROUP condition, as compared to the INDIVIDUAL condition (Panel A), and the difference is highly significant statistically ( $\mathrm{p}$-value $<0.01$ ). At the same time, we find no further increase in competitive preferences due to the group decision-making stage: The individual willingness to compete when being part of a group (IND_IN_GROUP) is similar to the willingness to compete when members make the decision jointly in a group (GROUP).

The observed effect of deciding in a group context on both the willingness to enter a competitive environment and to destroy resources in PDG and JDG supports the interpretation that deciding as part of a group increases aggressively competitive preferences. We further test this idea by combining choices from all three tasks. We classify subjects into four mutually exclusive types: Antisocial \& Competitive if they destroyed resources in both unconditional decisions in PDG and JDG and chose to enter competition in CG; Anti-social \& Not_competitive if they destroyed resources in PDG and JDG, but did not compete in CG; Not_anti-social \& Competitive if they competed in CG but have not harmed in either PDG or JDG; and finally, Not_anti-social \& Not_competitive if they chose not to compete in CG and not to harm in PDG or JDG.

Table 7 shows a clear pattern. Decision making in the GROUP condition doubles the prevalence of the Anti-social \& Competitive type, as compared to the INDIVIDUAL condition, from $16 \%$ to $32 \%$. At the same time, the prevalence of the Not_anti-social \& Not_competitive type diminishes by a similar magnitude. Decision making in groups does not influence the prevalence of

\footnotetext{
16 Typically, men in Western societies are observed to be more willing to enter competitive environments than women (Croson and Gneezy 2009; Niederle and Vesterlund 2007). In Uganda, we do not find a significant gender gap in the willingness to compete, despite having a relatively large sample of observations. This (non)finding is in line with recent studies which document that environmental factors, including culture, are important elements that shape gender differences in competitive preferences (Gneezy, Leonard, and List 2009; Almås et al. 2016).
} 
Anti-social \& Not_competitive and Not_anti-social \& Competitive types. Thus, the results reveal that decision making in groups does not have an independent but rather a joint effect on aggressively destructive and competitive behaviors, suggesting that decision making in groups increases willingness to harm others as well as willingness to compete. Note also, that the group effects in CG cannot be explained by pure spite because choosing the competitive contract and winning the competition does not influence the payoff of the counterpart.

Observation 6: Groups are 40\% more likely to enter a competitive contract than individuals are. The difference in the willingness to compete is driven by the effect of deciding in a group context on individual choices, rather than by group deliberation, and arises simultaneously with the decisions to harm others.

\section{CONCLUSIONS}

This paper provides strong evidence supporting the long-standing speculation across social sciences that decision-making in groups may have a dark side, by motivating hostile behavior towards outsiders even at one's own expense (Durlauf 1999; Hewstone, Rubin, and Willis 2002). We show that deciding in a group with randomly assigned real-life peers magnifies aggressive competitiveness: it (i) increases prevalence of anti-social behavior that improves the relative position of their own group but is costly for the decision maker, in-group members, and the victim, and (ii) makes people more willing to seek competition with outsiders. Next, using an integrated design that links literatures on group membership and group decision making, we demonstrate that this psychological effect of deciding in a group context on aggressive competitiveness is the prime source of the difference in the extent of prosocial behavior between unitary groups and individuals, a more important one than a shift towards self-regarding behavior associated with group deliberation. We establish these findings by implementing experiments in the field, among a large and diverse sample of adolescents in Central Europe and East Africa. We observe strikingly similar effects at both sites, which increases our confidence that the preference for competing aggressively when deciding in a group is a deeply rooted and generalizable behavioral response. 
Our results are consistent with two plausible behavioral mechanisms why making decisions in a group context may magnify aggressive competitiveness. First, individuals may derive utility from a shared experience of winning and beating outsiders. This additional utility from winning in teams could be an outcome of socialization and childhood experiences, given that a lot of competitive situations happen in group settings, or could also have evolutionary underpinnings, since relative success at a group level has been important element for survival during human history. Alternatively, banding individuals into arbitrary groups in which they make decisions can create a sense of common group identity (Tajfel et al. 1971; Chen and Li 2009), which in turn may manifest in hostility towards out-group members, in line with recent experiments among US undergraduates that employed minimal groups paradigm (Kranton et al. 2017).

While much of the existing literature focuses on the positive side of group-based (parochial) preferences, our findings suggest that the implications of its dark side need to be taken seriously, too. Recent micro-level studies from a range of post-conflict societies have highlighted how a parochial response to being exposed to a group conflict may facilitate post-conflict recovery by fostering collective actions and other forms of pro-social behavior at a local level (Bellows and Miguel 2009; Voors et al. 2012; Bauer et al. 2016). Similarly, in the context of military as well as business-oriented organizations, researchers have suggested that creating coherent organizational units has an efficiencyfostering benefit, due to the positive effect of creating cohesive groups on the willingness to cooperate with fellow workers (e.g., Akerlof and Kranton 2005; Goette, Huffman, and Meier 2006; Costa and Kahn 2001). However, our results suggest that such beneficial effects on the ability to cooperate in groups may come at the expense of greater aggressive competitiveness against members of other groups and organizations. We suspect that this latter effect may help to explain the ubiquitous nature of inter-group violence (Blattman and Miguel 2010; Keeley 1997) or mutually destructive competition within and across firms in market settings. It also strengthens the case for considering policies that attenuate narrow group identities (Fry 2012).

Also, recognizing the important role of competitiveness in determining individual career choices (e.g., Buser, Niederle, \& Oosterbeek, 2014), economists have recently started to work on 
identifying factors which may foster formation of competitiveness in individuals (Gneezy, Leonard, and List 2009; Andersen et al. 2013; Almås et al. 2016). Furthermore, the literature has focused on testing institutional designs, for example preferential treatment mechanisms and quotas, which promote competitiveness of women and can help to close gender gaps in willingness to compete (Sutter et al. 2016; Niederle, Segal, and Vesterlund 2013; Balafoutas and Sutter 2012). Our finding showing that the same causal factor, which increases willingness to enter competitive environment, simultaneously also raises the dark side of competitive behavior, willingness to harm others in order to gain in relative terms, and suggests that researchers and policy-makers should pay attention to a potential trade-off. While environments that foster the willingness to bear competitive pressures may lead to efficiency gains in some settings, they may also contribute to a greater prevalence of socially harmful behaviors.

Most broadly, our findings are in line with the view that anti-social behavior is not completely hard-wired, but can be, to some extent, activated by the nature of the surrounding social environment (Bowles 1998). Establishing the important role of cues of group competition (Abbink et al. 2010; Goette et al. 2012) or group membership, as in this paper, are the first steps towards greater understanding of situational factors that may trigger anti-social behavior. Exploring the role of other factors, such as emotional states, including stress or fear, or economic shocks, are fruitful areas for future research. 


\section{REFERENCES}

Abbink, Klaus, Jordi Brandts, Benedikt Herrmann, and Henrik Orzen. 2010. "Intergroup Conflict and Intra-Group Punishment in an Experimental Contest Game." American Economic Review 100 (1): 420-47. doi:10.1257/aer.100.1.420.

Abbink, Klaus, and Benedikt Herrmann. 2011. "The Moral Costs of Nastiness.” Economic Inquiry 49 (2): 631-33. doi:10.1111/j.1465-7295.2010.00309.x.

Abbink, Klaus, and Abdolkarim Sadrieh. 2009. "The Pleasure of Being Nasty." Economics Letters 105 (3). Elsevier B.V.: 306-8. doi:10.1016/j.econlet.2009.08.024.

Akerlof, George A, and Rachel E Kranton. 2005. "Identity and the Economics of Organizations." Journal of Economic Perspectives 19 (1): 9-32. doi:10.1257/0895330053147930.

Alesina, Alberto, and Eliana La Ferrara. 2005. "Ethnic Diversity and Economic Performance." Journal of Economic Literature 43 (3): 762-800.

Alexander, Marcus, and Fotini Christia. 2011. "Context Modularity of Human Altruism.” Science 334 (6061): 1392-94. doi:10.1126/science.1202599.

Allport, Gordon W. 1968. "The Historical Background of Modern Social Psychology." In The Handbook of Social Psychology, edited by G. Lindzey and E. Aronson, 1-80. Reading, MA: Addison-Wesley.

Almås, Ingvild, Alexander W Cappelen, Kjell G Salvanes, Erik Ø Sørensen, and Bertil Tungodden. 2016. "Willingness to Compete : Family Matters." Management Science 62 (8): 2149-62.

Ambrus, Attila, Ben Greiner, and Parag A. Pathak. 2015. "How Individual Preferences Are Aggregated in Groups: An Experimental Study." Journal of Public Economics 129. Elsevier B.V.: 1-13. doi:10.1016/j.jpubeco.2015.05.008.

Andersen, Steffen, Seda Ertac, Uri Gneezy, John A List, and Sandra Maximiano. 2013. "Gender, Competitiveness, and Socialization at Young Age: Evidence from a Matrilineal and a Patriarchal Society." Review of Economics and Statistics 95 (October): 1438-43. doi:10.1162/REST_a_00309.

Balafoutas, Loukas, Rudolf Kerschbamer, Martin Kocher, and Matthias Sutter. 2014. "Revealed Distributional Preferences: Individuals vs. Teams." Journal of Economic Behavior and Organization 108. Elsevier B.V.: 319-30. doi:10.1016/j.jebo.2013.12.012.

Balafoutas, Loukas, and Matthias Sutter. 2012. "Affirmative Action Policies Promote Women and Do Not Harm Efficiency in the Laboratory.” Science (New York, N.Y.) 335 (6068): 579-82. doi:10.1126/science.1211180.

Bauer, Michal, Christopher Blattman, Julie Chytilová, Joseph Henrich, Edward Miguel, and Tamar Mitts. 2016. “Can War Foster Cooperation?” Journal of Economic Perspectives 30 (3): 249-74.

Bauer, Michal, Jana Cahlíková, Julie Chytilová, and Tomáš Želinský. 2018. "Social Contagion of Ethnic Hostility." Proceedings of the National Academy of Sciences 115 (19): 4881-86.

Bellows, John, and Edward Miguel. 2009. "War and Local Collective Action in Sierra Leone." Journal of Public Economics 93 (11-12): 1144-57. doi:10.1016/j.jpubeco.2009.07.012.

Bernhard, Helen, Urs Fischbacher, and Ernst Fehr. 2006. "Parochial Altruism in Humans." Nature 442 (7105): 912-915.

Blattman, Christopher, and Edward Miguel. 2010. "Civil War.” Journal of Economic Literature 48 (1): 3-57.

Bornstein, Gary, and Ilan Yaniv. 1998. "Individual and Group Behavior in the Ultimatum Game: Are Groups More 'Rational ' Players?” Experimental Economics 1: 101-8. doi:10.1007/BF01426217.

Bowles, Samuel. 1998. "Endogenous Preferences: The Cultural Consequences of Markets and Other Economic Institutions." Journal of Economic Literature 36 (1): 75-111. doi:10.2307/2564952. 2008. "Conflict: Altruism's Midwife." Nature 456 (20): 326-27.

. 2009. "Did Warfare among Ancestral Hunter-Gatherers Affect the Evolution of Human Social Behaviors?" Science 324 (5932): 1293.

Buser, Thomas, Muriel Niederle, and Hessel Oosterbeek. 2014. "Gender, Competition and Career Choices." The Quarterly Journal of Economics 129 (3): 1409-47.

doi:10.1093/qje/qju009.Advance.

Camerer, C. 2003. Behavioral Game Theory: Experiments in Strategic Interaction. Princeton 
University Press Princeton, NJ.

Cason, Timoty, and Vai-Lam Mui. 1997. "A Laboratory Study in Group Polarisation in the Team Dictator Game." Economic Journal 107 (444): 1465-83.

Charness, Gary, Luca Rigotti, and Aldo Rustichini. 2007. "Individual Behavior and Group Membership." American Economic Review 97 (4): 1340-52. doi:10.2139/ssrn.894685.

Charness, Gary, and Matthias Sutter. 2012. "Groups Make Better Self-Interested Decisions." Journal of Economic Perspectives 26 (3): 157-76. doi:10.1257/jep.26.3.157.

Chen, Y., and S. X Li. 2009. "Group Identity and Social Preferences." American Economic Review 99 (1): 431-457.

Choi, Jung-Kyoo, and Samuel Bowles. 2007. "The Coevolution of Parochial Altruism and War." Science 318 (5850): 636-40. doi:10.1126/science.1144237.

Costa, Dora L, and Matthew E Kahn. 2003. "Cowards and Heroes: Group Loyalty in the American Civil War." Quarterly Journal of Economics 118 (2): 519-48.

Cox, James C. 2002. "Trust, Reciprocity, and Other-Regarding Preferences: Groups vs. Individuals and Males vs. Females." In Advances in Experimental Business Research, edited by R. Zwick and A. Rapoport. Kluwer Academic Publishers.

Croson, R., and U. Gneezy. 2009. "Gender Differences in Preferences." Journal of Economic Literature 47 (2): 448-474.

Deming, David J. 2011. “Better Schools, Less Crime?” The Quarterly Journal of Economics 126 (4): $2063-2115$.

Durlauf, Steven N. 1999. “The Case 'against' Social Capital.” FOCUS Newsletter for the Institute for Research on Poverty 20 (3): 1-5.

Easterly, William, and Ross Levine. 1997. "Africa's Growth Tragedy : Policies and Ethnic Divisions." The Quarterly Journal of Economics 112 (4): 1203-50.

Falk, A., E. Fehr, and U. Fischbacher. 2005. "Driving Forces behind Informal Sanctions." Econometrica 73 (6): 2017-2030.

Fehr, E., and U. Fischbacher. 2003. "The Nature of Human Altruism: Proximate Patterns and Evolutionary Origins." Nature 425: 785-91.

Fry, Douglas. 2012. "Life Without War." Science 336 (May): 879-84.

Gneezy, By Uri, Kenneth L Leonard, and John A List. 2009. "Gender Differences in Competition: Evidencel\ From a Matrilineal and a Patriarchal Society.” Econometrica 77 (5): 1637-64. doi:10.3982/ECTA6690.

Goette, Lorenz, David Huffman, and Stephan Meier. 2006. "The Impact of Group Membership on Cooperation and Norm Enforcement." American Economic Review 96 (2): 212-16. doi:10.1257/000282806777211658.

Goette, Lorenz, David Huffman, Stephan Meier, and Matthias Sutter. 2012. "Competition Between Organizational Groups: Its Impact on Altruistic and Antisocial Motivations." Management Science 58 (5): 948-60. doi:10.1287/mnsc.1110.1466.

Herrmann, B., C. Thoni, and S. Gachter. 2008. "Antisocial Punishment across Societies.” Science 319 (5868): 1362.

Hewstone, Miles, Mark Rubin, and Hazel Willis. 2002. "Intergroup Bias.” Annual Review of Psychology 53: 575-604.

Hoff, K., M. Kshetramade, and E. Fehr. 2011. "Caste and Punishment: The Legacy of Caste Culture in Norm Enforcement." The Economic Journal 121 (556): F449-F475.

Katreniak Celik, Dagmara. 2016. "Essays on Incentives and Information in Schools." CERGE-EI.

Keeley, L. H. 1997. War before Civilization. Oxford University Press, USA.

Kranton, Rachel, Matthew Pease, Seth Sanders, and Scott Huettel. 2017. "Deconstructing Bias: Individual Groupiness and Income Allocation."

Kugler, Tamar, Gary Bornstein, Martin G. Kocher, and Matthias Sutter. 2007. "Trust between Individuals and Groups: Groups Are Less Trusting than Individuals but Just as Trustworthy." Journal of Economic Psychology 28 (6): 646-57. doi:10.1016/j.joep.2006.12.003.

Kugler, Tamar, Edgar E Kausel, and Martin G. Kocher. 2012. "Review of Interactive Decision Making in Groups.” Cognitive Science 3 (4): 471-782.

Le Bon, Gustave. 1895. The Crowd. New York: Viking (1960).

Lochner, Lance, and Enrico Moretti. 2004. "The Effect of Education on Crime: Evidence from Prison 
Inmates, Arrests, and Self-Reports.” American Economic Review 94 (1): 155-89.

Luhan, Wolfgang J, Martin G Kocher, and Matthias Sutter. 2009. "Group Polarization in the Team Dictator Game Reconsidered.” Experimental Economics 12 (1): 26-41. doi:10.1007/s10683-0079188-7.

Niederle, Muriel, Carmit Segal, and Lise Vesterlund. 2013. "How Costly Is Diversity? Affirmative Action in Light of Gender Differences in Competitiveness." Management Science 59 (1): 1-16.

Niederle, Muriel, and Lise Vesterlund. 2007. "Do Women Shy Away From Competition? Do Men Compete Too Much?” The Quarterly Journal of Economics 122 (3): 1067-1101. doi:10.1162/qjec.122.3.1067.

Olsson, Ola, and Eyerusalem Siba. 2013. "Ethnic Cleansing or Resource Struggle in Darfur? An Empirical Analysis." Journal of Development Economics 103 (1). Elsevier B.V.: 299-312. doi:10.1016/j.jdeveco.2013.02.004.

Plato. n.d. "Republic." In The Dialogues of Plato, edited by B. Jowett (Ed. \& Trans.), 1-338. Oxford, England: Oxford University Press.

Prediger, Sebastian, Bjorn Vollan, and Benedikt Herrman. 2014. "Resource Scarcity and Antisocial Behavior." Journal of Public Economics, mimeo, 119: 1-9.

Publius. 1948. "Federalist No. 55." In The Federalist, edited by M. Beloff, 283-287. Oxford, England: Blackwell (Original work published 1788).

Robert, Christopher, and Peter J Carnevale. 1997. "Group Choice in Ultimatum Bargaining." Organizational Behavior and Human Decision Processes 72 (2): 256-79. doi:10.1006/obhd.1997.2738.

Sambanis, Nicholas, Jonah Schulhofer-Wohl, and Moses Shayo. 2012. "Parochialism as a Central Challenge in Counterinsurgency." Science 336 (6083): 805-8. doi:10.1126/science.1222304.

Song, Fei. 2008. "Trust and Reciprocity Behavior and Behavior Forecasts: Individuals vs. GroupRepresentatives." Games and Economic Behavior 62 (2): 675-96.

Sumner, William G. 1906. Fokways. New York: Ginn.

Sutter, Matthias. 2009. "Individual Behavior and Group Membership: Comment." American Economic Review 99 (5): 2247-57.

Sutter, Matthias, Daniela Glätzle-Rützler, Loukas Balafoutas, and Simon Czermak. 2016. "Cancelling out Early Age Gender Differences in Competition: An Analysis of Policy Interventions." Experimental Economics 19 (2): 412-32. doi:10.1007/s10683-015-9447-y.

Tajfel, Henry, M. G. Billing, R. P. Bundy, and Claude Flament. 1971. "Social Categorization and Intergroup Behavior.” European Journal of Social Psychology 1 (2): 149-78.

Voors, M., E. E Nillesen, P. Verwimp, E. H Bulte, R. Lensink, D. Van Soest, and W. Netherlands. 2012. "Violent Conflict and Behavior: A Field Experiment in Burundi." American Economic Review 102 (2): 941-64.

Wildschut, Tim, Brad Pinter, Jack L Vevea, Chester a Insko, and John Schopler. 2003. "Beyond the Group Mind: A Quantitative Review of the Interindividual-Intergroup Discontinuity Effect." Psychological Bulletin 129 (5): 698-722. doi:10.1037/0033-2909.129.5.698. 
TABLE 1: MEANS, INDIVIDUAL VS. GROUP DECISION-MAKING IN THE PRISONER'S DILEMMA GAME AND THE JOY OF DESTRUCTION GAME

\begin{tabular}{|c|c|c|c|c|c|c|c|c|c|}
\hline \multirow[t]{2}{*}{ Sample } & \multicolumn{3}{|c|}{ Both countries } & \multicolumn{3}{|c|}{ Slovakia } & \multicolumn{3}{|c|}{ Uganda } \\
\hline & $\begin{array}{c}\text { INDIVI } \\
\text { DUAL } \\
(1)\end{array}$ & $\begin{array}{c}\text { GROUP } \\
(2)\end{array}$ & $\begin{array}{c}\text { p.p. } \\
\text { difference } \\
\text { (p-value) } \\
(3)\end{array}$ & $\begin{array}{c}\text { INDIVI } \\
\text { DUAL } \\
(4)\end{array}$ & $\begin{array}{c}\text { GROUP } \\
(5)\end{array}$ & $\begin{array}{c}\text { p.p. } \\
\text { difference } \\
\text { (p-value) } \\
(6)\end{array}$ & $\begin{array}{c}\text { INDIVI } \\
\text { DUAL } \\
(7)\end{array}$ & $\begin{array}{c}\text { GROUP } \\
(8)\end{array}$ & $\begin{array}{c}\text { p.p. } \\
\text { difference } \\
\text { (p-value) } \\
(9)\end{array}$ \\
\hline \multicolumn{10}{|c|}{ Panel A: Joy of Destruction game, proportion of destructive choices } \\
\hline Unconditional decision & 0.46 & 0.51 & $6(0.03)$ & 0.32 & 0.42 & $10(0.02)$ & 0.53 & 0.59 & $7(0.05)$ \\
\hline Conditional decision, if partner non-destructive & 0.39 & 0.46 & $7(0.01)$ & 0.29 & 0.38 & $9(0.03)$ & 0.44 & 0.52 & $8(0.02)$ \\
\hline Conditional decision, if partner destructive & 0.71 & 0.69 & $-2(0.38)$ & 0.55 & 0.51 & $-4(0.34)$ & 0.80 & 0.84 & $5(0.08)$ \\
\hline Beliefs: counterpart destructive & 0.54 & 0.53 & $-1(0.66)$ & 0.43 & 0.43 & $0(0.94)$ & 0.60 & 0.62 & $2(0.62)$ \\
\hline Observations & 648 & 763 & & 222 & 346 & & 426 & 417 & \\
\hline \multicolumn{10}{|c|}{ Panel B: Prisoner's Dilemma game, proportion of non-cooperative choices } \\
\hline Unconditional decision & 0.61 & 0.81 & $20(0.00)$ & 0.67 & 0.82 & $15(0.00)$ & 0.57 & 0.79 & $22(0.00)$ \\
\hline Conditional decision, if partner cooperative & 0.49 & 0.66 & $17(0.00)$ & 0.69 & 0.80 & $12(0.00)$ & 0.39 & 0.54 & $15(0.00)$ \\
\hline Conditional decision, if partner non-cooperative & 0.82 & 0.89 & $7(0.00)$ & 0.87 & 0.91 & $4(0.12)$ & 0.80 & 0.87 & $8(0.00)$ \\
\hline Beliefs: counterpart non-cooperative & 0.66 & 0.70 & $4(0.08)$ & 0.66 & 0.73 & $7(0.07)$ & 0.66 & 0.68 & $2(0.50)$ \\
\hline Observations & 649 & 763 & & 222 & 346 & & 427 & 417 & \\
\hline \multicolumn{10}{|c|}{ Panel C: Types based on unconditional choices in PDG and JDG } \\
\hline Self-regarding & 0.27 & 0.36 & $9(0.00)$ & 0.44 & 0.48 & $4(0.41)$ & 0.18 & 0.25 & $8(0.01)$ \\
\hline Anti-social & 0.34 & 0.45 & $11(0.00)$ & 0.23 & 0.35 & $12(0.00)$ & 0.39 & 0.54 & $14(0.00)$ \\
\hline Pro-social & 0.28 & 0.13 & $-14(0.00)$ & 0.24 & 0.11 & $-13(0.00)$ & 0.29 & 0.15 & $-14(0.00)$ \\
\hline Ambiguous & 0.12 & 0.06 & $-6(0.00)$ & 0.09 & 0.07 & $-2(0.37)$ & 0.13 & 0.06 & $-8(0.00)$ \\
\hline Observations & 647 & 763 & & 222 & 346 & & 425 & 417 & \\
\hline
\end{tabular}


TABLE 2: THE EFFECT OF GROUP DECISION-MAKING ON THE PREVALENCE OF ANTI-SOCIAL BEHAVIOR

\begin{tabular}{|c|c|c|c|c|c|c|}
\hline \multirow[t]{2}{*}{ Dependent variable } & JD game & PD game & \multicolumn{4}{|c|}{ Behavioral types based on PDG and JDG } \\
\hline & $\begin{array}{c}\text { Destructive } \\
\text { choice } \\
\text { (1) }\end{array}$ & $\begin{array}{l}\text { Non- } \\
\text { cooperative } \\
\text { choice } \\
(2)\end{array}$ & $\begin{array}{l}\text { Anti- } \\
\text { social } \\
(3) \\
\end{array}$ & $\begin{array}{l}\text { Self- } \\
\text { regarding } \\
(4)\end{array}$ & $\begin{array}{c}\text { Pro-social } \\
(5)\end{array}$ & $\begin{array}{c}\text { Ambiguous } \\
(6)\end{array}$ \\
\hline \multicolumn{7}{|l|}{ Panel A: Both countries } \\
\hline GROUP & $\begin{array}{c}0.08 * * * \\
(0.03)\end{array}$ & $\begin{array}{c}0.19 * * * \\
(0.02)\end{array}$ & $\begin{array}{c}0.13 * * * \\
(0.03)\end{array}$ & $\begin{array}{c}0.06 * * \\
(0.03)\end{array}$ & $\begin{array}{c}-0.14 * * * \\
(0.02)\end{array}$ & $\begin{array}{c}-0.06 * * * \\
(0.02)\end{array}$ \\
\hline Mean INDIVIDUAL & 0.46 & 0.61 & 0.34 & 0.27 & 0.28 & 0.12 \\
\hline Observations & 1,411 & 1,412 & 1,410 & 1,410 & 1,410 & 1,410 \\
\hline \multicolumn{7}{|l|}{ Panel B: Slovakia } \\
\hline GROUP & $\begin{array}{l}0.10 * * \\
(0.04)\end{array}$ & $\begin{array}{c}0.15 * * * \\
(0.04)\end{array}$ & $\begin{array}{c}0.12 * * * \\
(0.04)\end{array}$ & $\begin{array}{c}0.04 \\
(0.04)\end{array}$ & $\begin{array}{c}-0.13 * * * \\
(0.03)\end{array}$ & $\begin{array}{l}-0.02 \\
(0.02)\end{array}$ \\
\hline Mean INDIVIDUAL & 0.32 & 0.67 & 0.23 & 0.44 & 0.24 & 0.09 \\
\hline Observations & 568 & 568 & 568 & 568 & 568 & 568 \\
\hline \multicolumn{7}{|l|}{ Panel C: Uganda } \\
\hline GROUP & $\begin{array}{l}0.07 * \\
(0.03)\end{array}$ & $\begin{array}{c}0.22 * * * \\
(0.03)\end{array}$ & $\begin{array}{c}0.14 * * * \\
(0.03)\end{array}$ & $\begin{array}{c}0.08 * * * \\
(0.03)\end{array}$ & $\begin{array}{c}-0.14 * * * \\
(0.03)\end{array}$ & $\begin{array}{c}-0.08 * * * \\
(0.02)\end{array}$ \\
\hline Mean INDIVIDUAL & 0.53 & 0.57 & 0.39 & 0.18 & 0.29 & 0.13 \\
\hline Observations & 843 & 844 & 842 & 842 & 842 & 842 \\
\hline
\end{tabular}

Notes: Columns 1-2 report marginal effects from logit estimates, Columns 3-6 report marginal effects from multinomial logit estimates, standard errors in parentheses. $* * *$ denotes $\mathrm{p}<0.01$, $* * \mathrm{p}<0.05$, and $* \mathrm{p}<0.1$. The dependent variables in Columns 1 and 2 are unconditional destructive and non-cooperative choices in the Joy of Destruction game and the Prisoner's Dilemma game, respectively. The dependent variable in Columns 3-6 is behavioral type classified based on unconditional choices in the PDG and JDG, as defined in Table 1. GROUP indicates that the choice was made in a group of three randomly matched subjects, who had time to deliberate and reach a joint decision. The omitted category is the INDIVIDUAL condition, where choices were made in isolation. In Panel A we control for a dummy variable indicating whether the observation is from the Ugandan or the Slovak sample. 


\begin{tabular}{|c|c|c|c|c|c|c|}
\hline \multirow[t]{2}{*}{ Dependent variable } & \multicolumn{3}{|c|}{ JD game } & \multicolumn{3}{|c|}{ PD game } \\
\hline & $\begin{array}{c}\text { Destructive } \\
\text { conditional on } \\
\text { counterpart non- } \\
\text { destructive } \\
\text { (1) }\end{array}$ & $\begin{array}{l}\text { Destructive } \\
\text { conditional on } \\
\text { counterpart } \\
\text { destructive } \\
\text { (2) }\end{array}$ & $\begin{array}{c}\text { Beliefs } \\
\text { counterpart } \\
\text { destructive } \\
\text { (3) }\end{array}$ & $\begin{array}{c}\text { Non- } \\
\text { cooperative } \\
\text { conditional } \\
\text { on } \\
\text { counterpart } \\
\text { cooperative } \\
\text { (4) }\end{array}$ & $\begin{array}{c}\text { Non- } \\
\text { cooperative, } \\
\text { conditional on } \\
\text { counterpart non- } \\
\text { cooperative } \\
\text { (5) }\end{array}$ & $\begin{array}{l}\text { Beliefs } \\
\text { counterp } \\
\text { art non- } \\
\text { cooperati } \\
\text { ve } \\
\text { (6) }\end{array}$ \\
\hline \multicolumn{7}{|l|}{ Panel A: Both countries } \\
\hline GROUP & $\begin{array}{c}0.09 * * * \\
(0.03)\end{array}$ & $\begin{array}{c}0.01 \\
(0.03)\end{array}$ & $\begin{array}{c}0.01 \\
(0.03)\end{array}$ & $\begin{array}{c}0.15^{* * *} \\
(0.03)\end{array}$ & $\begin{array}{c}0.06 * * * \\
(0.02)\end{array}$ & $\begin{array}{c}0.04 \\
(0.03)\end{array}$ \\
\hline Mean INDIVIDUAL & 0.39 & 0.71 & 0.54 & 0.49 & 0.82 & 0.66 \\
\hline Observations & 1,412 & 1,412 & 1,412 & 1,413 & 1,412 & 1,413 \\
\hline \multicolumn{7}{|l|}{ Panel B: Slovakia } \\
\hline GROUP & $\begin{array}{l}0.09 * * \\
(0.04)\end{array}$ & $\begin{array}{l}-0.04 \\
(0.04)\end{array}$ & $\begin{array}{l}-0.00 \\
(0.04)\end{array}$ & $\begin{array}{c}0.12 * * * \\
(0.04)\end{array}$ & $\begin{array}{c}0.04 \\
(0.03)\end{array}$ & $\begin{array}{l}0.07 * \\
(0.04)\end{array}$ \\
\hline $\begin{array}{l}\text { Mean INDIVIDUAL } \\
\text { Observations }\end{array}$ & $\begin{array}{l}0.29 \\
568 \\
\end{array}$ & $\begin{array}{r}0.55 \\
568 \\
\end{array}$ & $\begin{array}{r}0.43 \\
568 \\
\end{array}$ & $\begin{array}{l}0.69 \\
568 \\
\end{array}$ & $\begin{array}{l}0.87 \\
568 \\
\end{array}$ & $\begin{array}{r}0.66 \\
568 \\
\end{array}$ \\
\hline \multicolumn{7}{|l|}{ Panel C: Uganda } \\
\hline GROUP & $\begin{array}{l}0.08 * * \\
(0.03)\end{array}$ & $\begin{array}{l}0.05^{*} \\
(0.03)\end{array}$ & $\begin{array}{c}0.02 \\
(0.03)\end{array}$ & $\begin{array}{c}0.15^{* * *} \\
(0.03)\end{array}$ & $\begin{array}{c}0.08 * * * \\
(0.03)\end{array}$ & $\begin{array}{c}0.02 \\
(0.03)\end{array}$ \\
\hline Mean INDIVIDUAL & 0.44 & 0.80 & 0.60 & 0.39 & 0.80 & 0.66 \\
\hline Observations & 844 & 844 & 844 & 845 & 844 & 845 \\
\hline
\end{tabular}

Notes: Columns 1-6 report marginal effects from logit estimates, standard errors in parentheses. $* * *$ denotes $\mathrm{p}<0.01, * * \mathrm{p}<0.05$, and $* \mathrm{p}<0.1$.

The dependent variables in Columns 1-3 and 4-6 are conditional choices and beliefs in the Joy of Destruction game and the Prisoner's

Dilemma game, respectively. GROUP indicates that the choice was made jointly in a group of three subjects; the omitted category is the INDIVIDUAL condition. In Panel A we control for a dummy variable indicating whether the observation is from the Ugandan or the Slovak sample. 


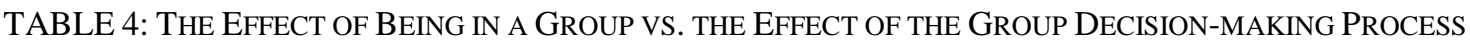

\begin{tabular}{|c|c|c|c|c|c|c|c|}
\hline \multirow{2}{*}{$\begin{array}{l}\text { Sample } \\
\text { Dependent variable }\end{array}$} & \multicolumn{2}{|c|}{ Both countries } & \multicolumn{2}{|c|}{ Slovakia } & \multicolumn{3}{|c|}{ Uganda } \\
\hline & $\begin{array}{l}\text { JDG: } \\
\text { Destructive } \\
\text { choice } \\
(1)\end{array}$ & $\begin{array}{l}\text { PDG: } \\
\text { Non-cooperative } \\
\text { choice } \\
(2)\end{array}$ & $\begin{array}{l}\text { JDG: } \\
\text { Destructive } \\
\text { choice } \\
\text { (3) }\end{array}$ & $\begin{array}{c}\text { PDG: } \\
\text { Non-cooperative } \\
\text { choice } \\
(4)\end{array}$ & $\begin{array}{l}\text { JDG: } \\
\text { Destructive } \\
\text { choice } \\
\text { (5) }\end{array}$ & $\begin{array}{c}\text { PDG: } \\
\text { Non-cooperative } \\
\text { choice } \\
(6)\end{array}$ & $\begin{array}{c}\text { Competitiveness } \\
\text { game: Choosing } \\
\text { competitive contract } \\
\text { (7) }\end{array}$ \\
\hline \multicolumn{8}{|c|}{ Panel A: Effect of being in a group (comparison to INDIVIDUAL) } \\
\hline IND_IN_GROUP & $\begin{array}{c}0.09 * * * \\
(0.02)\end{array}$ & $\begin{array}{c}0.10 * * * \\
(0.02)\end{array}$ & $\begin{array}{c}0.12 * * * \\
(0.04)\end{array}$ & $\begin{array}{c}0.08 * * \\
(0.04)\end{array}$ & $\begin{array}{c}0.07 * * \\
(0.03)\end{array}$ & $\begin{array}{c}0.10 * * * \\
(0.03)\end{array}$ & $\begin{array}{c}0.20 * * * \\
(0.03)\end{array}$ \\
\hline Mean INDIVIDUAL & 0.46 & 0.61 & 0.32 & 0.67 & 0.53 & 0.57 & 0.39 \\
\hline Observations & 2,905 & 2,923 & 1,243 & 1,258 & 1,662 & 1,665 & 1,671 \\
\hline \multicolumn{8}{|c|}{ Panel B: Effect of group decision-making process (comparison to IND_IN_GROUP) } \\
\hline GROUP & $\begin{array}{l}-0.01 \\
(0.02)\end{array}$ & $\begin{array}{c}0.09 * * * \\
(0.01)\end{array}$ & $\begin{array}{l}-0.03 \\
(0.02)\end{array}$ & $\begin{array}{c}0.07 * * * \\
(0.02)\end{array}$ & $\begin{array}{l}-0.00 \\
(0.02)\end{array}$ & $\begin{array}{c}0.11 * * * \\
(0.02)\end{array}$ & $\begin{array}{l}-0.03 \\
(0.02)\end{array}$ \\
\hline Mean IND_IN_GROUP & 0.53 & 0.71 & 0.44 & 0.75 & 0.60 & 0.68 & 0.58 \\
\hline Observations & 3,020 & 3,037 & 1,367 & 1,382 & 1,653 & 1,655 & 1,660 \\
\hline
\end{tabular}


TABLE 5: GROUP DECISIONS: AGGREGATION OF INDIVIDUAL PREFERENCES

\begin{tabular}{|c|c|c|c|c|}
\hline & $(1)$ & (2) & (3) & $(4)$ \\
\hline \multicolumn{5}{|c|}{ Panel A: Joy of Destruction game } \\
\hline & \multicolumn{4}{|c|}{ Destructive choice in JDG } \\
\hline & $\begin{array}{c}\text { No group } \\
\text { member } \\
\text { wants to } \\
\text { destroy }\end{array}$ & $\begin{array}{c}\text { One group } \\
\text { member } \\
\text { wants to } \\
\text { destroy }\end{array}$ & $\begin{array}{c}\text { Two group } \\
\text { members } \\
\text { want to } \\
\text { destroy }\end{array}$ & $\begin{array}{c}\text { All group } \\
\text { members } \\
\text { want to } \\
\text { destroy }\end{array}$ \\
\hline Both countries & 0.12 & 0.30 & 0.65 & 0.90 \\
\hline Observations & 167 & 177 & 201 & 196 \\
\hline Slovakia & 0.12 & 0.25 & 0.58 & 0.94 \\
\hline Observations & 98 & 96 & 80 & 65 \\
\hline Uganda & 0.12 & 0.36 & 0.69 & 0.89 \\
\hline Observations & 69 & 81 & 121 & 131 \\
\hline
\end{tabular}

Panel B: Prisoner's dilemma game

\begin{tabular}{ccccc}
\cline { 2 - 4 } & \multicolumn{4}{c}{ Non-cooperative choice in PDG } \\
\cline { 2 - 4 } & $\begin{array}{c}\text { No group } \\
\text { member } \\
\text { wants to } \\
\text { defect }\end{array}$ & $\begin{array}{c}\text { One group } \\
\text { member } \\
\text { wants to } \\
\text { defect }\end{array}$ & $\begin{array}{c}\text { Two group } \\
\text { members } \\
\text { want to defect }\end{array}$ & $\begin{array}{c}\text { Three group } \\
\text { members } \\
\text { want to defect }\end{array}$ \\
\cline { 2 - 5 } Both countries & 0.38 & 0.56 & 0.83 & 0.95 \\
Observations & 68 & 117 & 205 & 359 \\
Slovakia & 0.29 & 0.61 & 0.82 & 0.94 \\
Observations & 21 & 46 & 97 & 180 \\
Uganda & 0.43 & 0.52 & 0.83 & 0.97 \\
Observations & 47 & 71 & 108 & 179 \\
\hline
\end{tabular}

Panel C: Competitiveness game

\begin{tabular}{lcccc}
\cline { 2 - 5 } & \multicolumn{4}{c}{ Competition choice in CG } \\
\cline { 2 - 5 } & $\begin{array}{c}\text { No group } \\
\text { member } \\
\text { wants to } \\
\text { compete }\end{array}$ & $\begin{array}{c}\text { One group } \\
\text { member } \\
\text { wants to } \\
\text { compete }\end{array}$ & $\begin{array}{c}\text { Two group } \\
\text { members } \\
\text { want to } \\
\text { compete }\end{array}$ & $\begin{array}{c}\text { All group } \\
\text { members } \\
\text { want to } \\
\text { compete }\end{array}$ \\
\cline { 2 - 5 } Observations & 0.06 & 0.35 & 0.62 & 0.91 \\
\hline
\end{tabular}

Notes: Aggregation of individual preferences for the group outcome elicited in the GROUP condition prior to the group decision-making stage (IND_IN_GROUP) into the joint GROUP decision achieved after group deliberation. Panel A presents the prevalence of destructive GROUP choices in the Joy of Destruction game, disaggregated by the number of group members who wanted to destroy. Panel B presents the prevalence of non-cooperative GROUP choices in the Prisoner's Dilemma game, disaggregated by the number of group members who wanted to defect in IND_IN_GROUP. Panel C presents the prevalence of competition GROUP choices in the Competitiveness game, disaggregated by the number of group members who wanted to compete. 
TABLE 6: MEANS, INDIVIDUAL VS. GROUP DECISION-MAKING IN THE COMPETITIVENESS GAME (UgANDA)

\begin{tabular}{|c|c|c|c|}
\hline \multirow[t]{2}{*}{ Sample } & \multicolumn{3}{|c|}{ Uganda } \\
\hline & $\begin{array}{l}\text { INDIVIDUAL } \\
\text { (1) }\end{array}$ & $\begin{array}{c}\text { GROUP } \\
(2)\end{array}$ & $\begin{array}{c}\text { p.p. difference } \\
\text { (p-value) } \\
(3)\end{array}$ \\
\hline \multicolumn{4}{|l|}{ Panel A: Competitiveness game } \\
\hline Willingness to compete: choice of compet. contr. in round 3 & 0.39 & 0.56 & $17(0.00)$ \\
\hline Confidence: believe that won in round 2 (forced tournament) & 0.50 & 0.68 & $18(0.00)$ \\
\hline Performance in round 1 (piece-rate) & 3.83 & 3.73 & $-0.11(0.57)$ \\
\hline Performance in round 2 (forced tournament) & 4.54 & 4.23 & $-0.31(0.03)$ \\
\hline \multicolumn{4}{|l|}{ Panel B: Types based on unconditional choices in PDG, JDG and CG } \\
\hline Anti-social \& Competitive & 0.16 & 0.32 & $16(0.00)$ \\
\hline Anti-social \& Not_competitive & 0.23 & 0.21 & $-2(0.53)$ \\
\hline Not_anti-social \& Competitive & 0.22 & 0.23 & $0(0.77)$ \\
\hline Not_anti-social \& Not_competitive & 0.38 & 0.23 & $-15(0.00)$ \\
\hline Observations & 428 & 417 & \\
\hline
\end{tabular}

Notes: Panel A reports the likelihood of choosing a competitive contract, beliefs, and performance in the Competitiveness game (CG). In Panel $\mathrm{B}$, subjects are classified into four mutually exclusive behavioral types based on CG choices and unconditional choices in PDG and JDG: Antisocial \& Competitive types destroyed resources in both PDG and JDG and chose to enter competition in CG; Anti-social \& Not_competitive types destroyed resources in PDG and JDG, but did not compete in CG; Not_anti-social \& Competitive types competed in CG but have not harmed in PDG or in JDG; and finally, Not_anti-social \& Not_competitive types chose to not compete in CG and to not harm in PDG or JDG. A more detailed classification of types is presented in Table A.8. All differences are presented in percentage points and tested using a Chisquare test. 
TABLE 7: THE EFFECT OF GROUP DECISION-MAKING ON COMPETITIVE BEHAVIOR (UGANDA)

\begin{tabular}{|c|c|c|c|c|c|c|}
\hline \multirow[t]{3}{*}{ Dependent variable } & \multicolumn{2}{|c|}{$\begin{array}{l}\text { Willingness to } \\
\text { compete in CG }\end{array}$} & \multicolumn{4}{|c|}{ Behavioral types based CG, PDG, and JDG } \\
\hline & \multicolumn{2}{|c|}{$\begin{array}{c}\text { Choosing } \\
\text { competitive contract }\end{array}$} & \multirow{2}{*}{$\begin{array}{c}\text { Anti-social } \\
\& \\
\text { Competitive } \\
(3)\end{array}$} & \multirow{2}{*}{$\begin{array}{c}\text { Anti-social \& } \\
\text { Not_competitive } \\
(4)\end{array}$} & \multirow{2}{*}{$\begin{array}{l}\text { Not_anti-social } \\
\& \text { Competitive } \\
\text { (5) }\end{array}$} & \multirow{2}{*}{$\begin{array}{c}\text { Not_anti-social \& } \\
\text { Not_competitive } \\
(6)\end{array}$} \\
\hline & (1) & (2) & & & & \\
\hline \multirow[t]{2}{*}{ GROUP } & $0.17 * * *$ & $0.17 * * *$ & $0.16^{* * *}$ & -0.02 & 0.01 & $-0.15 * * *$ \\
\hline & $(0.03)$ & $(0.04)$ & $(0.03)$ & $(0.03)$ & $(0.03)$ & $(0.03)$ \\
\hline Confidence: believe that & & $0.08 * *$ & & & & \\
\hline won in round 2 & & $(0.04)$ & & & & \\
\hline \multirow[t]{2}{*}{ Performance in round 1} & & -0.00 & & & & \\
\hline & & $(0.02)$ & & & & \\
\hline \multirow[t]{2}{*}{ Performance in round 2} & & $0.02 *$ & & & & \\
\hline & & $(0.01)$ & & & & \\
\hline Mean INDIVIDUAL & 0.39 & 0.39 & 0.16 & 0.23 & 0.22 & 0.38 \\
\hline Observations & 845 & 835 & 832 & 832 & 832 & 832 \\
\hline
\end{tabular}

Notes: Columns 1-2 report marginal effects from logit estimates, Columns 3-6 report marginal effects from multinomial logit estimates, standard errors in parentheses. $* * *$ denotes $\mathrm{p}<0.01, * * \mathrm{p}<0.05$, and $* \mathrm{p}<0.1$. The dependent variable in Columns $1-2$ is the willingness to compete in CG (equal to one if the tournament payoff scheme was chosen over the piece-rate scheme in round 3). In Column 2, we control for belief as to whether the result of the competition will be winning, and for performance in the task in the first and second rounds, which are potentially endogenous to GROUP treatment. The dependent variable in Columns 3-6 is behavioral type classified based on CG choices and unconditional choices in PDG and JDG (four mutually exclusive ones), as described in Table 6. 


\section{Figure 1. PAyoff MATRICES}

PANEL A: SLOVAKIA (IN EUR)

a) Joy of Destruction game

Player B:

Player A:

\begin{tabular}{|c|c|c|}
\hline & Non-destructive & Destructive \\
\hline Non-destructive & 2,2 & $1.8,1$ \\
\hline Destructive & $1.8,1$ & $0.8,0.8$ \\
\hline
\end{tabular}

b) Prisoner's Dilemma game

Player B:

Player A:

\begin{tabular}{|c|c|c|}
\hline & Cooperate & Defect \\
\hline Cooperate & $1.6,1.6$ & $0.8,2$ \\
\hline Defect & $2,0.8$ & $1.2,1.2$ \\
\hline
\end{tabular}

PANEL B: UGANDA (IN USH)

a) Joy of Destruction game

Player B:

\begin{tabular}{|c|c|c|c|}
\cline { 2 - 4 } & & Non-destructive & Destructive \\
\cline { 2 - 4 } Player A: & Non-destructive & 1000,1000 & 500,900 \\
\cline { 2 - 4 } & Destructive & 900,500 & 400,400 \\
\cline { 2 - 4 }
\end{tabular}

b) Prisoner's Dilemma game

Player B:

Player A:

\begin{tabular}{|c|c|c|}
\hline & Cooperate & Defect \\
\hline Cooperate & 800,800 & 400,1000 \\
\hline Defect & 1000,400 & 600,600 \\
\hline
\end{tabular}


Figure 2. The EFFeCt of Group DeCiSION-MAKING ON CHOICES IN THE JoY OF DeSTRUCTION GAME AND the

\section{PRISONER'S DILEMMA GAME}

PANEL A: SLOVAKIA

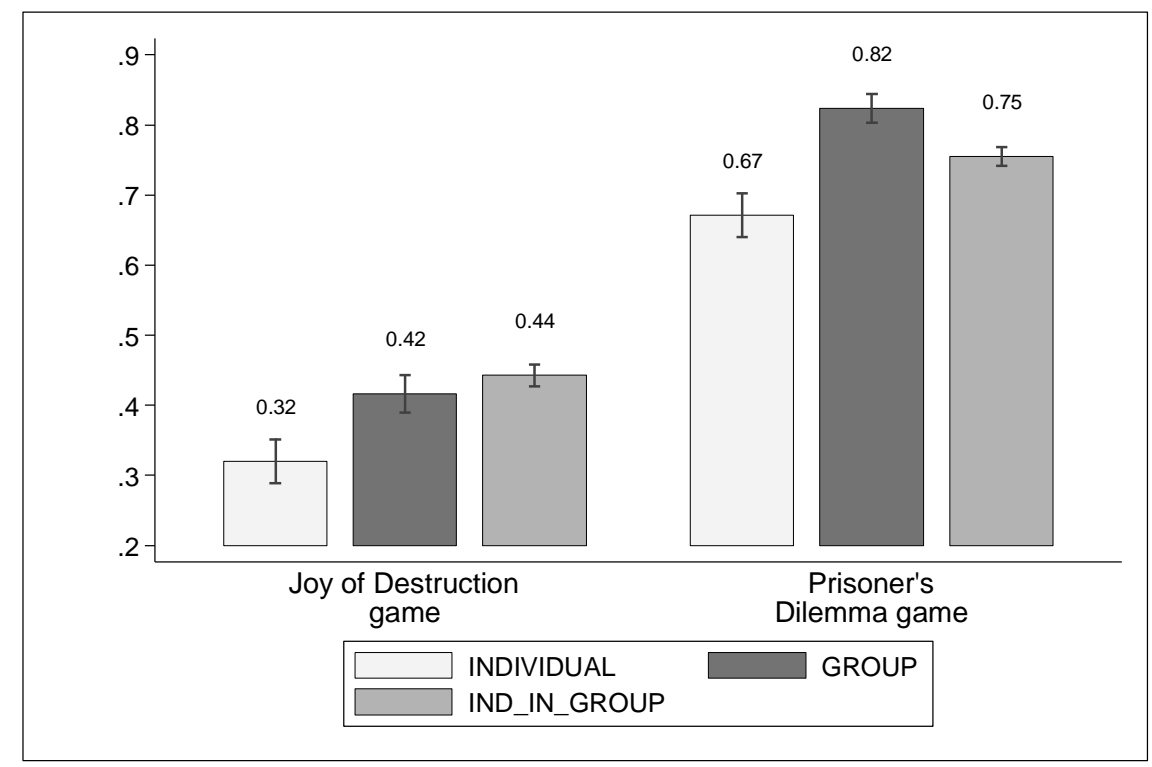

PANEL B: UGANDA

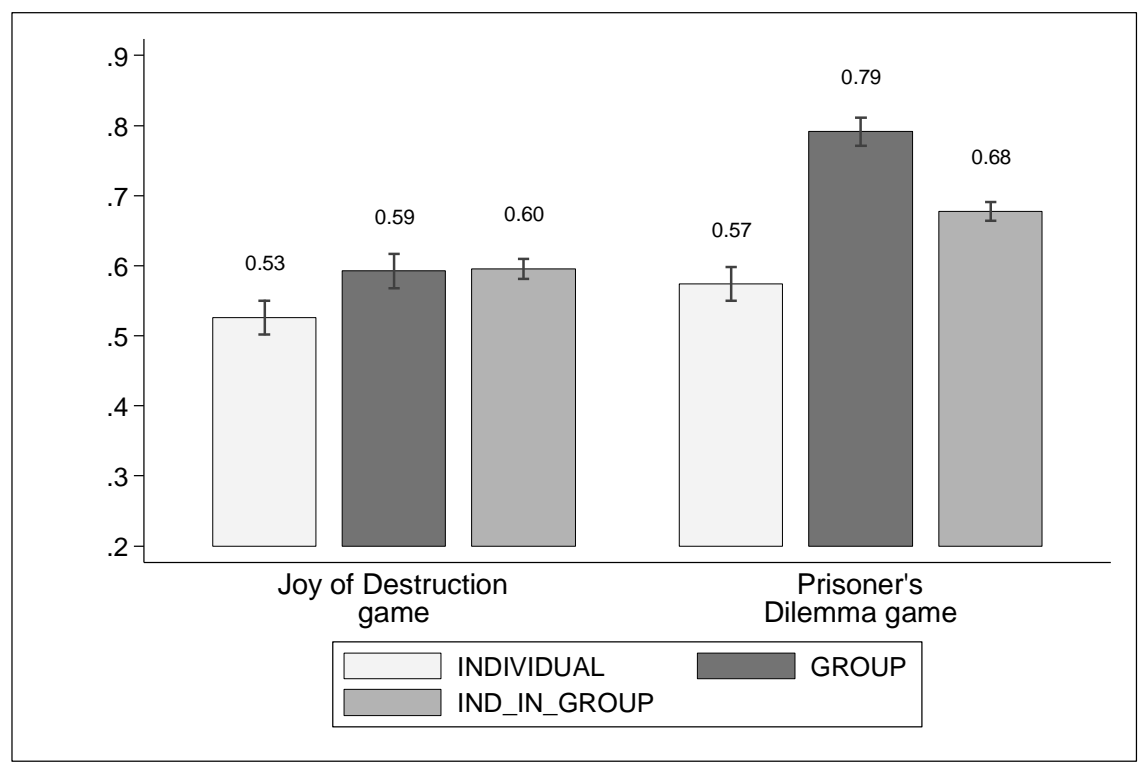

Notes: The proportion of non-cooperative choices in the Prisoner's Dilemma game and destructive choices in the Joy of Destruction game. Choices in the INDIVIDUAL condition were made in isolation, while choices in the GROUP condition were made in a group of three randomly matched subjects, who had time to deliberate and reach a joint decision. IND_IN_GROUP choices present the individual preference regarding the group decision, elicited on an individual level prior to the group decision-making stage. Panel A presents results for the Slovak sample, while Panel B presents results for the Ugandan sample. Bars indicate mean \pm standard errors. 
Figure 3. THE EFFECT OF GROUP DECISION-MAKING ON THE WILLINGNESS TO COMPETE IN THE COMPETITIVENESS

GAME.

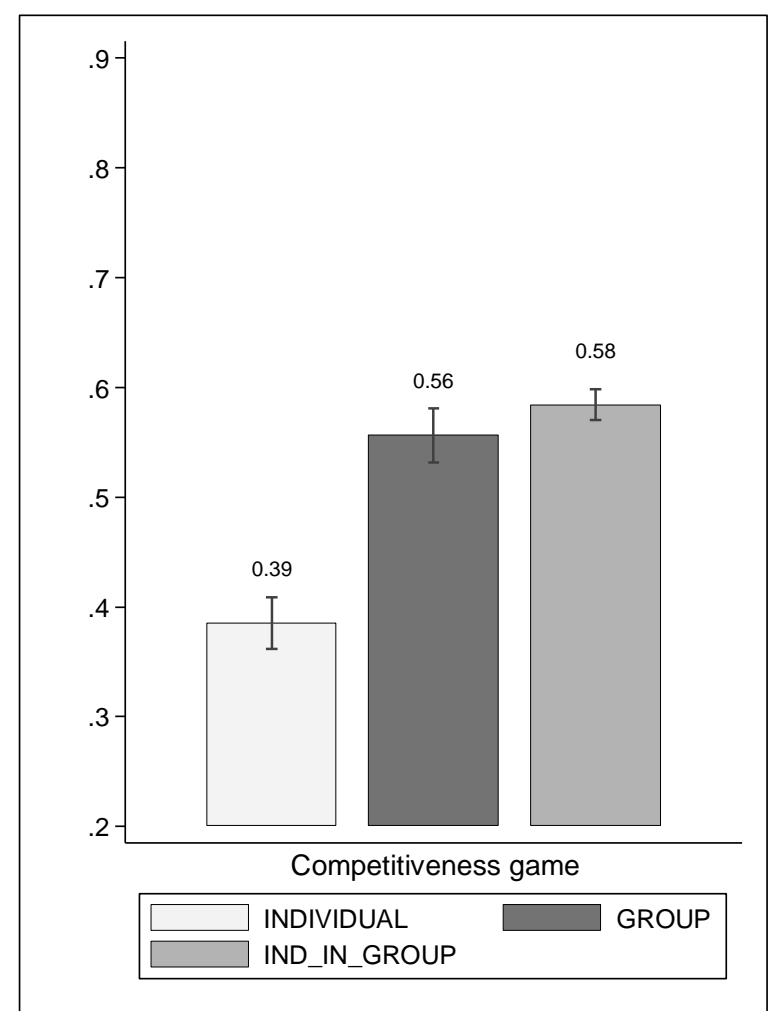

Notes: The proportion of competitive contract choices (willingness to compete) in the Competitiveness game. Competitive contract choice denotes that the tournament payoff scheme was chosen over the piece-rate scheme in round 3 of the CG. Choices in the INDIVIDUAL condition were made in isolation, while choices in the GROUP condition were made in a group of three randomly matched subjects. IND_IN_GROUP choices present the individual preference regarding the group decision, elicited on an individual level prior to the group decisionmaking stage. Competitiveness game was administered only in the Ugandan sample. Bars indicate mean \pm standard errors. 


\section{Anti-social Behavior in Groups}

Michal Bauer, Jana Cahlíková, Dagmara Celik Katreniak, Julie Chytilová, Lubomír Cingl, and Tomáš Želinský

\section{Supplementary Online Appendix A}

This file contains appendix figure and tables

Appendix Figure A.1

Appendix Tables A.1-A.7

Experimental protocol for Slovakia and Uganda is available upon request. 


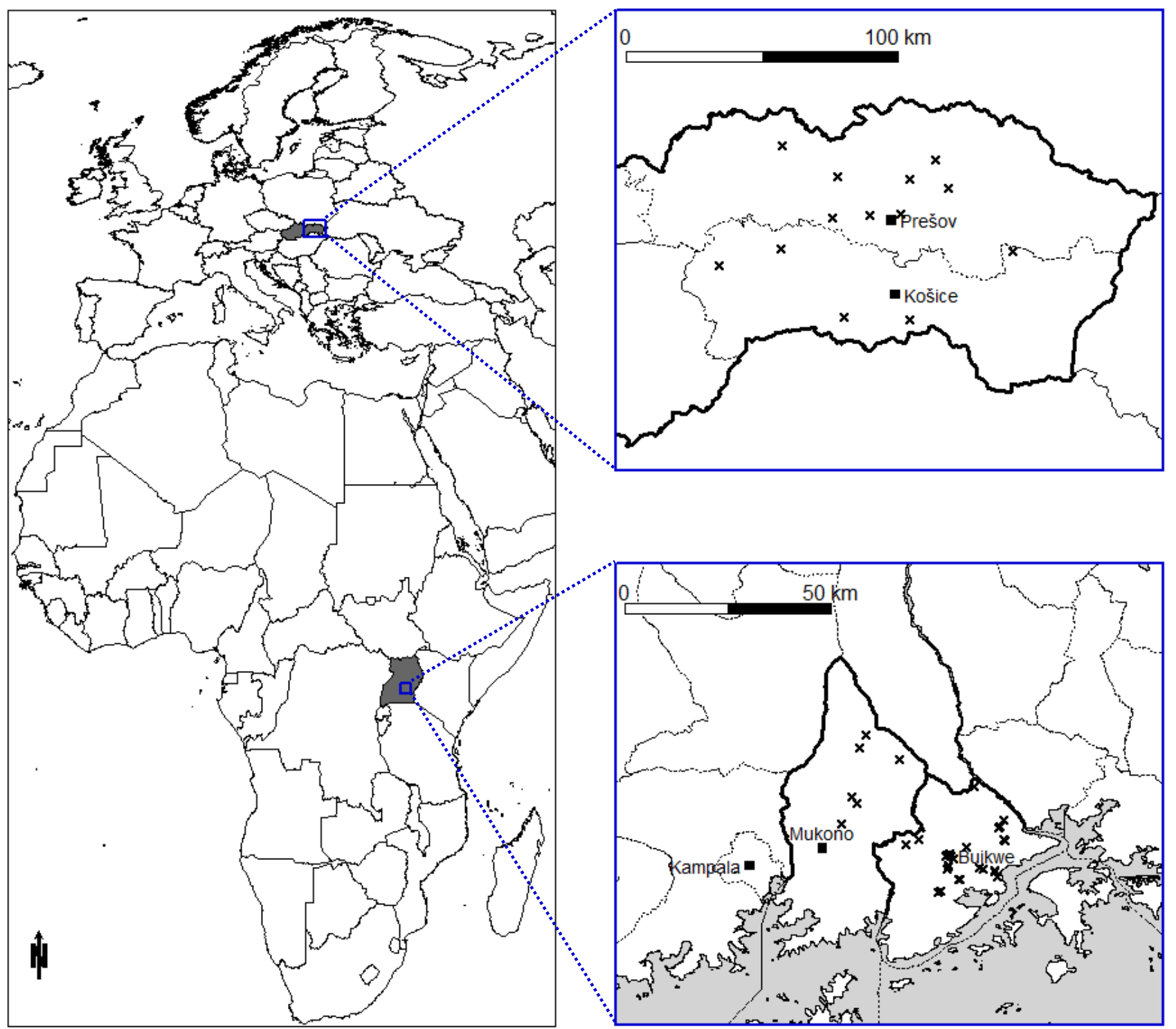

Notes: The data were collected in 13 schools in Eastern Slovakia (Kosice and Presov districts, upper-right picture) and 34 schools in rural Uganda (Buikwe and Mukono districts, bottom-right picture). Maps were created using (c) EuroGeographics for the administrative boundaries "NUTS 2013" and "Countries 2014" shapefiles and (c) The World Bank: Energydata.info Uganda Energy Sector GIS Working Group "Uganda - Lakes (2014)" and "Uganda Districts 2013" shapefiles in R environment (R Core Team, 2017) and its libraries: "sp" (Pebesme \& Bivand, 2005; Bivand, Pebesma \& Gomez-Rubio, 2013), "latticeExtra" (Sarkar \& Andrews, 2016), "maptools" (Bivand \& Lewin-Koh, 2017), "rgdal" (Bivand, Keitt \& Rowlingson, 2017). ${ }^{17}$

${ }^{17}$ References for the R environment libraries: Bivand, R., Keitt, T., and Rowlingson, B. (2017). rgdal: Bindings for the 'Geospatial' Data Abstraction Library. R package version. 1.2-12; Bivand, R. and Lewin-Koh, N. (2017). maptools: Tools for Reading and Handling Spatial Objects. R package version 0.9-2; Bivand, R., Pebesma, E. J., Gomez-Rubio, V. (2013). Applied spatial data analysis with R, Second edition. Springer, NY; Pebesma, E.J., Bivand, R.S. (2005). Classes and methods for spatial data in R. R News 5 (2); R Core Team (2017). R: A language and environment for statistical computing. R Foundation for Statistical Computing, Vienna, Austria; Sarkar, D. and Andrews, F. (2016). latticeExtra: Extra Graphical Utilities Based on Lattice. R package version 0.6-28. 


\section{APPEndix TABLeS}

TABLE A.1: DeSCRIPTIVE STATISTICS AND RANDOMIZATION CHECKS

\begin{tabular}{|c|c|c|c|c|c|}
\hline \multirow[b]{3}{*}{ Sample } & $(1)$ & $(2)$ & (3) & $(4)$ & $(5)$ \\
\hline & \multicolumn{5}{|c|}{ Means across treatments } \\
\hline & $\begin{array}{l}\text { Whole } \\
\text { sample }\end{array}$ & INDIVIDUAL & GROUP & $\begin{array}{c}\text { diff } \\
\text { (p-value) }\end{array}$ & $\mathrm{N}$ \\
\hline \multicolumn{6}{|l|}{ Panel A: Slovakia } \\
\hline Female & 0.51 & 0.53 & 0.50 & 0.56 & 630 \\
\hline Age & 13.83 & 13.74 & 13.85 & 0.19 & 625 \\
\hline Number of siblings & 1.86 & 1.89 & 1.85 & 0.97 & 571 \\
\hline Mother unemployed & 0.26 & 0.23 & 0.27 & 0.46 & 569 \\
\hline Father unemployed & 0.09 & 0.14 & 0.07 & 0.04 & 557 \\
\hline Mother's education: high school & 0.78 & 0.79 & 0.77 & 0.75 & 489 \\
\hline Mother's education: university & 0.19 & 0.19 & 0.20 & 0.88 & 489 \\
\hline Father's education: high school & 0.81 & 0.77 & 0.82 & 0.32 & 474 \\
\hline Father's education: university & 0.17 & 0.18 & 0.17 & 0.71 & 474 \\
\hline Family owns a car & 0.89 & 0.87 & 0.90 & 0.31 & 600 \\
\hline Family owns a computer & 0.94 & 0.96 & 0.94 & 0.31 & 615 \\
\hline Family owns a TV & 0.98 & 0.99 & 0.98 & 0.45 & 615 \\
\hline Family owns a tablet & 0.33 & 0.26 & 0.34 & 0.12 & 442 \\
\hline Cognitive skills $(0=\min , 4=\max )$ & 2.97 & 2.89 & 2.99 & 0.20 & 629 \\
\hline $\mathrm{N}$ & 630 & 111 & 519 & & \\
\hline \multicolumn{6}{|l|}{ Panel B: Uganda } \\
\hline Female & 0.56 & 0.57 & 0.56 & 0.81 & 1621 \\
\hline Age & 14.94 & 14.98 & 14.92 & 0.37 & 1611 \\
\hline Number of siblings & 7.15 & 7.19 & 7.13 & 0.88 & 1595 \\
\hline Mother unemployed & 0.30 & 0.31 & 0.30 & 0.75 & 1534 \\
\hline Father unemployed & 0.16 & 0.17 & 0.16 & 0.94 & 1409 \\
\hline Mother's education: high school & 0.55 & 0.60 & 0.54 & 0.06 & 1290 \\
\hline Mother's education: university & 0.11 & 0.09 & 0.11 & 0.25 & 1290 \\
\hline Father's education: high school & 0.59 & 0.62 & 0.58 & 0.32 & 1155 \\
\hline Father's education: university & 0.15 & 0.15 & 0.16 & 0.65 & 1155 \\
\hline Electricity at home & 0.38 & 0.38 & 0.38 & 0.82 & 1613 \\
\hline Family owns a car & 0.16 & 0.17 & 0.16 & 0.39 & 1619 \\
\hline Family owns a TV & 0.35 & 0.35 & 0.35 & 0.90 & 1619 \\
\hline Family owns a radio & 0.84 & 0.86 & 0.83 & 0.10 & 1619 \\
\hline English test score $(0=\min , 50=\max )$ & 17.71 & 17.46 & 17.80 & 0.55 & 1613 \\
\hline Math test score $(0=\min , 50=\max )$ & 14.94 & 14.62 & 15.05 & 0.52 & 1612 \\
\hline $\mathrm{N}$ & 1679 & 428 & 1251 & & \\
\hline
\end{tabular}

Notes: Descriptive statistics of the Slovak sample (Panel A) and of the Ugandan sample (Panel B). Columns 2-3 present means for subjects in the INDIVIDUAL and the GROUP conditions. Experimental balance is tested in Column 4 using a Chi-square test for categorical and Wilcoxon rank-sum test for cardinal variables. Variable "Cognitive skills" is equal to the number of correctly answered Raven's Progressive Matrices (4=max). For all variables, the values are missing for unspecified answers and for "I do not know" answers; Column 5 gives the number of non-missing values. 
TABLE A.2: EXPERIMENTAL DESIGN OVERVIEW

\begin{tabular}{lcc}
\hline \hline & & \\
\hline Experimental tasks & Slovakia & Uganda \\
Joy of Destruction Game (JDG): unconditional and conditional choices, beliefs & yes & yes \\
Prisoner's Dilemma Game (PDG): unconditional and conditional choices, beliefs & yes & yes \\
Competitiveness Game (CG) & no & yes \\
Experimental manipulations & & \\
INDIVIDUAL & yes & yes \\
GROUP & & yes \\
GROUP_GROUP & yes & no \\
GROUP_IND & yes & yes \\
IND_IN_GROUP & yes & no \\
IND_ON_BEHALF & yes & \\
Experimental counterpart & & no \\
from the same school \& the same ethnic group & yes \\
from a different school \& the same ethnic group & yes \\
from a different school \& a different ethnic group & yes & no \\
\hline
\end{tabular}


TABLE A.3: THE EFFECT OF GROUP DECISION-MAKING ON ANTI-SOCIAL BEHAVIOR, ROBUSTNESS CHECKS

\begin{tabular}{|c|c|c|c|c|c|c|c|c|c|c|}
\hline & JDG & PDG & JDG & PDG & JDG & PDG & JDG & PDG & JDG & PDG \\
\hline & $\begin{array}{c}\text { Destruct } \\
\text { ive } \\
\text { choice } \\
\text { (1) }\end{array}$ & $\begin{array}{l}\text { Non- } \\
\text { cooperat } \\
\text { ive } \\
\text { choice } \\
(2) \\
\end{array}$ & $\begin{array}{c}\text { Destruct } \\
\text { ive } \\
\text { choice } \\
(3)\end{array}$ & $\begin{array}{l}\text { Non- } \\
\text { cooperati } \\
\text { ve } \\
\text { choice } \\
(4)\end{array}$ & $\begin{array}{c}\text { Destruc } \\
\text { tive } \\
\text { choice } \\
(5)\end{array}$ & $\begin{array}{l}\text { Non- } \\
\text { cooperat } \\
\text { ive } \\
\text { choice } \\
(6) \\
\end{array}$ & $\begin{array}{c}\text { Destruc } \\
\text { tive } \\
\text { choice } \\
(7)\end{array}$ & $\begin{array}{l}\text { Non- } \\
\text { cooperat } \\
\text { ive } \\
\text { choice } \\
(8)\end{array}$ & $\begin{array}{c}\text { Destruct } \\
\text { ive } \\
\text { choice } \\
(9)\end{array}$ & $\begin{array}{l}\text { Non- } \\
\text { cooperat } \\
\text { ive } \\
\text { choice } \\
(10) \\
\end{array}$ \\
\hline \multicolumn{11}{|l|}{ Panel A: Both countries } \\
\hline GROUP & $\begin{array}{c}0.09 * * * \\
(0.03)\end{array}$ & $\begin{array}{c}0.18^{* * *} \\
(0.02)\end{array}$ & $\begin{array}{c}0.10 * * * \\
(0.03)\end{array}$ & $\begin{array}{c}0.19 * * * \\
(0.03)\end{array}$ & $\begin{array}{c}0.08 * * * \\
(0.03)\end{array}$ & $\begin{array}{c}0.20 * * * \\
(0.02)\end{array}$ & $\begin{array}{c}0.09 * * * \\
(0.03)\end{array}$ & $\begin{array}{c}0.20 * * * \\
(0.02)\end{array}$ & $\begin{array}{c}0.08^{* * *} \\
(0.03)\end{array}$ & $\begin{array}{c}0.19 * * * \\
(0.02)\end{array}$ \\
\hline Observations & 1,411 & 1,411 & 1,210 & 1,178 & 1,411 & 1,412 & 1,411 & 1,412 & 1,411 & 1,412 \\
\hline \multicolumn{11}{|l|}{ Panel B: Slovakia } \\
\hline GROUP & $\begin{array}{c}0.11^{* *} \\
(0.04)\end{array}$ & $\begin{array}{c}0.16^{* * * *} \\
(0.04)\end{array}$ & $\begin{array}{c}0.12 * * * \\
(0.04)\end{array}$ & $\begin{array}{c}0.17 * * * \\
(0.04)\end{array}$ & $\begin{array}{c}0.09 * * \\
(0.04)\end{array}$ & $\begin{array}{c}0.16^{* * * *} \\
(0.04)\end{array}$ & $\begin{array}{c}0.10^{* *} \\
(0.04)\end{array}$ & $\begin{array}{c}0.16^{* * *} \\
(0.04)\end{array}$ & $\begin{array}{l}0.10^{* *} \\
(0.04)\end{array}$ & $\begin{array}{c}0.15 * * * \\
(0.04)\end{array}$ \\
\hline Observations & 568 & 567 & 507 & 483 & 568 & 568 & 568 & 568 & 568 & 568 \\
\hline \multicolumn{11}{|l|}{ Panel C: Uganda } \\
\hline GROUP & $\begin{array}{c}0.07 * * \\
(0.04)\end{array}$ & $\begin{array}{c}0.22 * * * \\
(0.03)\end{array}$ & $\begin{array}{c}0.08 * * \\
(0.04)\end{array}$ & $\begin{array}{c}0.21 * * * \\
(0.03)\end{array}$ & $\begin{array}{c}0.07 * * \\
(0.03)\end{array}$ & $\begin{array}{c}0.22 * * * \\
(0.03)\end{array}$ & $\begin{array}{c}0.07 * * \\
(0.04)\end{array}$ & $\begin{array}{c}0.23 * * * \\
(0.03)\end{array}$ & $\begin{array}{l}0.06^{*} \\
(0.03)\end{array}$ & $\begin{array}{c}0.22 * * * \\
(0.03)\end{array}$ \\
\hline Observations & 841 & 844 & 703 & 695 & 843 & 844 & 843 & 844 & 843 & 844 \\
\hline Controlling for the level of understanding & $\mathrm{Y}$ & $\mathrm{Y}$ & & & & & & & & \\
\hline Only observations with perfect understanding & & & $\mathrm{Y}$ & $\mathrm{Y}$ & & & & & & \\
\hline Order effects, experimenter fixed effects & & & & & Y & Y & & & & \\
\hline School fixed effects & & & & & & & Y & $\mathrm{Y}$ & & \\
\hline School grade fixed effects & & & & & & & & & $\mathrm{Y}$ & $\mathrm{Y}$ \\
\hline
\end{tabular}

Notes: Marginal effects from logit estimates. $* * *$ denotes $\mathrm{p}<0.01$, $* * \mathrm{p}<0.05$, and $* \mathrm{p}<0.1$. The dependent variable is an unconditional destructive choice in the Joy of Destruction Game (Columns 1, 3, 5, 7, 9) and a non-cooperative choice in the Prisoner's Dilemma game (Columns 2, 4, 6, 8, 10). In Columns 1-2, we control for dummy variables indicating how many comprehension questions (out of 4) were answered correctly in the given game. In Uganda, the number of comprehension questions answered correctly in the GROUP condition is coded as the maximum among the group members. In Columns 3-4, we keep only the observations where all four control questions were answered correctly for the given game. In Columns 5-6, we control for the order effects (the order of the PDG and JDG, the order of the ethnicity conditions in Slovakia) and for the experimenter fixed effects. In Columns 7-8 and 9-10, we control for school fixed-effects and for school-grade fixed effects, respectively. GROUP indicates that the choice was made in a group of three randomly matched subjects, who had time to deliberate and reach a joint decision. The omitted category is the INDIVIDUAL condition, where choices were made in isolation. In Panel A we control for a dummy variable indicating whether the observation is from the Ugandan or the Slovak sample. 
TABLE A.4: THE EFFECT OF GROUP DECISION-MAKING ON ANTI-SOCIAL BEHAVIOR, BY THE ETHNICITY OF THE COUNTERPART (SLOVAKIA)

\begin{tabular}{|c|c|c|c|c|c|c|}
\hline & \multirow{2}{*}{$\begin{array}{c}\text { JD game } \\
\begin{array}{c}\text { Destructive } \\
\text { choice }\end{array}\end{array}$} & PD game & \multicolumn{4}{|c|}{ Behavioral types based on JDG and PDG } \\
\hline & & $\begin{array}{c}\text { Non-cooperative } \\
\text { choice } \\
(2) \\
\end{array}$ & $\begin{array}{c}\text { Anti-social } \\
\text { (3) }\end{array}$ & $\begin{array}{l}\text { Self- } \\
\text { regarding } \\
(4)\end{array}$ & $\begin{array}{c}\text { Pro-Social } \\
(5)\end{array}$ & $\begin{array}{c}\text { Ambiguous } \\
(6)\end{array}$ \\
\hline \multicolumn{7}{|c|}{ Panel A: SLOVAKIA, counterpart from the same ethnic group (majority ethnicity) } \\
\hline GROUP & $\begin{array}{c}0.09 \\
(0.06)\end{array}$ & $\begin{array}{c}0.14 * * \\
(0.05)\end{array}$ & $\begin{array}{c}0.08 \\
(0.06)\end{array}$ & $\begin{array}{c}0.06 \\
(0.06)\end{array}$ & $\begin{array}{c}-0.14 * * * \\
(0.05)\end{array}$ & $\begin{array}{c}0.01 \\
(0.03)\end{array}$ \\
\hline Mean INDIVIDUAL & 0.30 & 0.69 & 0.23 & 0.46 & 0.25 & 0.07 \\
\hline Observations & 257 & 257 & 257 & 257 & 257 & 257 \\
\hline \multicolumn{7}{|c|}{ Panel A: SLOVAKIA, counterpart from a distinct ethnic group (Roma ethnicity) } \\
\hline GROUP & $\begin{array}{c}0.13 * * \\
(0.06)\end{array}$ & $\begin{array}{c}0.15^{* * * *} \\
(0.06)\end{array}$ & $\begin{array}{c}0.14 * * \\
(0.06)\end{array}$ & $\begin{array}{c}0.01 \\
(0.06)\end{array}$ & $\begin{array}{c}-0.14 * * * \\
(0.05)\end{array}$ & $\begin{array}{l}-0.01 \\
(0.03)\end{array}$ \\
\hline Mean INDIVIDUAL & 0.32 & 0.68 & 0.23 & 0.44 & 0.23 & 0.09 \\
\hline Observations & 257 & 257 & 257 & 257 & 257 & 257 \\
\hline
\end{tabular}

Notes: Columns 1-2 report marginal effects from logit estimates, Columns 3-6 report marginal effects from multinomial logit estimates, standard errors in parentheses. $* * *$ denotes $\mathrm{p}<0.01$, $* * \mathrm{p}<0.05$, and $* \mathrm{p}<0.1$. Panel A presents results for the condition where experimental counterparts were from the same (majority) ethnicity as the decision-makers. Panel B presents results for the condition where experimental counterparts were from different (Roma) ethnic group than the decision-makers. In both conditions, the counterparts came from an unspecified school in the same region, and thus were completely unknown to the decision-makers. Ethnicity was signaled using a list of 20 names of potential counterparts (ten male and ten female names), where the list contained either typical majority names, or typical Roma names. Note that five percent of our sample are of Roma ethnicity, and thus their social distance is presumably smaller towards counterparts in the Roma condition. Therefore, when studying the role of social distance, we restrict our sample to majority-ethnicity individuals and groups composed of exclusively majority-ethnicity subjects, for interpretation reasons. In any case, the results similar when using the full sample (available upon request). The dependent variables in Columns 1 and 2 are unconditional destructive and non-cooperative choices in the Joy of Destruction game and the Prisoner's Dilemma game, respectively. The dependent variable in Columns 3-6 is behavioral type classified based on unconditional choices in the PDG and JDG, as defined in Table 1. GROUP indicates that the choice was made in a group of three randomly matched subjects, who had time to deliberate and reach a joint decision. The omitted category is the INDIVIDUAL condition, where choices were made in isolation. 
TABLE A.5: THE EFFECT OF GROUP DECISION-MAKING ON THE PREVALENCE OF ANTI-SOCIAL BEHAVIOR, CONTROLLING FOR BELIEFS

\begin{tabular}{|c|c|c|c|c|c|c|}
\hline \multirow[t]{3}{*}{ Dependent variable } & \multicolumn{3}{|c|}{ JD game } & \multicolumn{3}{|c|}{ PD game } \\
\hline & \multicolumn{3}{|c|}{ Destructive choice } & \multicolumn{3}{|c|}{ Non-cooperative choice } \\
\hline & $(1)$ & $(2)$ & (3) & (4) & $(5)$ & $(6)$ \\
\hline \multicolumn{7}{|l|}{ Panel A: Both countries } \\
\hline \multirow[t]{2}{*}{ GROUP } & $0.08 * * *$ & $0.08 * * *$ & $0.09 * *$ & $0.19 * * *$ & $0.19 * * *$ & $0.17 * * *$ \\
\hline & $(0.03)$ & $(0.03)$ & $(0.04)$ & $(0.02)$ & $(0.02)$ & $(0.04)$ \\
\hline \multirow[t]{2}{*}{ Beliefs } & & $0.25 * * *$ & $0.26 * * *$ & & $0.21 * * *$ & $0.19 * * *$ \\
\hline & & $(0.03)$ & $(0.04)$ & & $(0.03)$ & $(0.04)$ \\
\hline \multirow[t]{2}{*}{ Beliefs*GROUP } & & & -0.02 & & & 0.03 \\
\hline & & & $(0.06)$ & & & $(0.05)$ \\
\hline Observations & 1,411 & 1,411 & 1,411 & 1,411 & 1,411 & 1,411 \\
\hline \multicolumn{7}{|l|}{ Panel B: Slovakia } \\
\hline \multirow[t]{2}{*}{ GROUP } & $0.10 * *$ & $0.10 * *$ & 0.05 & $0.15 * * *$ & $0.14 * * *$ & $0.12 * *$ \\
\hline & $(0.04)$ & $(0.04)$ & $(0.06)$ & $(0.04)$ & $(0.04)$ & $(0.06)$ \\
\hline \multirow[t]{2}{*}{ Beliefs } & & $0.28 * * *$ & $0.21 * * *$ & & $0.18 * * *$ & $0.17 * * *$ \\
\hline & & $(0.04)$ & $(0.07)$ & & $(0.04)$ & $(0.06)$ \\
\hline \multirow[t]{2}{*}{ Beliefs*GROUP } & & & 0.12 & & & 0.03 \\
\hline & & & $(0.09)$ & & & $(0.07)$ \\
\hline Observations & 568 & 568 & 568 & 568 & 568 & 568 \\
\hline \multicolumn{7}{|l|}{ Panel C: Uganda } \\
\hline \multirow[t]{2}{*}{ GROUP } & $0.07 *$ & $0.07 *$ & $0.13 * *$ & $0.22 * * *$ & $0.22 * * *$ & $0.20 * * *$ \\
\hline & $(0.03)$ & $(0.03)$ & $(0.05)$ & $(0.03)$ & $(0.03)$ & $(0.05)$ \\
\hline \multirow[t]{2}{*}{ Beliefs } & & $0.23 * * *$ & $0.28 * * *$ & & $0.22 * * *$ & $0.20 * * *$ \\
\hline & & $(0.03)$ & $(0.05)$ & & $(0.04)$ & $(0.05)$ \\
\hline \multirow[t]{2}{*}{ Beliefs*GROUP } & & & -0.11 & & & 0.04 \\
\hline & & & $(0.07)$ & & & $(0.07)$ \\
\hline Observations & 843 & 843 & 843 & 843 & 843 & 843 \\
\hline
\end{tabular}

Notes: Columns 1-6 report marginal effects from logit estimates, standard errors in parentheses. $* * *$ denotes $\mathrm{p}<0.01$, ** $\mathrm{p}<0.05$, and $* \mathrm{p}<0.1$. The dependent variables in Columns 1-3 and 4-6 are unconditional destructive and non-cooperative choices in the Joy of Destruction game and the Prisoner's Dilemma game, respectively. GROUP indicates that the choice was made in a group of three randomly matched subjects, who had time to deliberate and reach a joint decision. The omitted category is the INDIVIDUAL condition, where choices were made in isolation. The variable Beliefs is equal to one if the decision-maker (group or individual) believes that the counterpart is destructive (Columns 1-3) or noncooperative (Columns 4-6). Note that as Beliefs are potentially endogenous to GROUP treatment, and thus this analysis should be taken with a grain of salt. In Panel A we control for a dummy variable indicating whether the observation is from the Ugandan or the Slovak sample. 
TABLE A.6: GROUP DECISION-MAKING, BY COUNTERPART BEING AN INDIVIDUAL OR A GROUP

\begin{tabular}{|c|c|c|c|c|c|c|}
\hline & $\begin{array}{l}\text { INDIVIDUAL } \\
(1) \\
\end{array}$ & $\begin{array}{c}\text { GROUP_IND } \\
(2) \\
\end{array}$ & $\begin{array}{c}\text { GROUP_GROUP } \\
\text { (3) }\end{array}$ & $\begin{array}{c}\text { p.p. difference } \\
\text { (p-value) } \\
(2)-(1)\end{array}$ & $\begin{array}{c}\text { p.p. difference } \\
\text { (p-value) } \\
(3)-(1)\end{array}$ & $\begin{array}{c}\text { p.p. difference } \\
\text { (p-value) } \\
(3)-(2)\end{array}$ \\
\hline \multicolumn{7}{|l|}{ Joy of destruction game } \\
\hline Unconditional decision & 0.32 & 0.44 & 0.39 & $12(0.01)$ & $7(0.15)$ & $-5(0.32)$ \\
\hline Conditional decision, if partner non-hostile & 0.29 & 0.37 & 0.40 & $8(0.09)$ & $10(0.03)$ & $2(0.68)$ \\
\hline Conditional decision, if partner hostile & 0.55 & 0.52 & 0.49 & $-3(0.60)$ & $-6(0.28)$ & $-3(0.59)$ \\
\hline Beliefs: counterpart destructive & 0.43 & 0.44 & 0.41 & $1(0.77)$ & $-2(0.68)$ & $-4(0.50)$ \\
\hline \multicolumn{7}{|l|}{ Prisoner's dilemma game } \\
\hline Unconditional decision & 0.67 & 0.79 & 0.86 & $12(0.01)$ & $19(0.00)$ & $7(0.07)$ \\
\hline Conditional decision, if partner cooperative & 0.68 & 0.78 & 0.83 & $9(0.04)$ & $14(0.00)$ & $5(0.25)$ \\
\hline Conditional decision, if partner non-cooperative & 0.87 & 0.91 & 0.91 & $4(0.23)$ & $4(0.18)$ & $0(0.88)$ \\
\hline Beliefs: counterpart non-cooperative & 0.66 & 0.72 & 0.73 & $7(0.16)$ & $7(0.11)$ & $1(0.86)$ \\
\hline Observations & 222 & 174 & 172 & & & \\
\hline
\end{tabular}

Notes: The prevalence of destructive choices and beliefs in the Joy of Destruction game and non-cooperative choices and beliefs in the Prisoner's Dilemma game, by whether the experimental counterpart in the GROUP condition was an individual (Column 2) or a group (Column 3). The experimental counterpart in the INDIVIDUAL condition (Column 1) was always an individual. INDIVIDUAL indicates that the choice was made in isolation, GROUP indicates that the choice was made in a group of three randomly matched subjects, who had time to deliberate and reach a joint decision. All differences are presented in percentage points and tested using a Chi-square test. 
TABLE A.7: BEHAVIORAL TYPES, BASED ON CONDITIONAL CHOICES IN JDG AND PDG

\begin{tabular}{|c|c|c|c|c|c|}
\hline \multirow[t]{2}{*}{ Dependent variable } & \multicolumn{5}{|c|}{ Type based on conditional choices in JDG and PDG } \\
\hline & $\begin{array}{c}\text { Anti-social } \\
(1)\end{array}$ & $\begin{array}{l}\text { Self- } \\
\text { regarding } \\
(2)\end{array}$ & $\begin{array}{c}\text { Pro-Social } \\
(3)\end{array}$ & $\begin{array}{c}\text { Conditional } \\
\text { cooperator } \\
(4)\end{array}$ & $\begin{array}{c}\text { Other } \\
(5)\end{array}$ \\
\hline \multicolumn{6}{|l|}{ Panel A: Both countries } \\
\hline Group & $\begin{array}{c}0.10^{* * * *} \\
(0.02)\end{array}$ & $\begin{array}{c}0.03 * * * \\
(0.01)\end{array}$ & $\begin{array}{c}-0.03^{* * *} \\
(0.01)\end{array}$ & $\begin{array}{c}-0.06^{* * *} \\
(0.02)\end{array}$ & $\begin{array}{l}-0.05^{*} \\
(0.03)\end{array}$ \\
\hline Observations & 1,411 & 1,411 & 1,411 & 1,411 & 1,411 \\
\hline \multicolumn{6}{|l|}{ Panel B: Slovakia } \\
\hline Group & $\begin{array}{c}0.04 \\
(0.03)\end{array}$ & $\begin{array}{c}0.11^{* * *} \\
(0.04)\end{array}$ & $\begin{array}{c}-0.03^{* *} \\
(0.01)\end{array}$ & $\begin{array}{l}-0.04 \\
(0.03)\end{array}$ & $\begin{array}{l}-0.08^{*} \\
(0.04)\end{array}$ \\
\hline Mean INDIVIDUAL & 0.17 & 0.19 & 0.04 & 0.13 & 0.48 \\
\hline Observations & 568 & 568 & 568 & 568 & 568 \\
\hline \multicolumn{6}{|l|}{ Panel C: Uganda } \\
\hline Group & $\begin{array}{c}0.13 * * * \\
(0.03)\end{array}$ & $\begin{array}{c}0.01 \\
(0.01)\end{array}$ & $\begin{array}{c}-0.03^{* *} \\
(0.01)\end{array}$ & $\begin{array}{c}-0.07 * * \\
(0.03)\end{array}$ & $\begin{array}{l}-0.05 \\
(0.03)\end{array}$ \\
\hline Mean INDIVIDUAL & 0.17 & 0.01 & 0.05 & 0.29 & 0.47 \\
\hline Observations & 843 & 843 & 843 & 843 & 843 \\
\hline
\end{tabular}

Notes: Columns 1-5 marginal effects from multinomial logit estimates, standard errors in parentheses. $* * *$ denotes $\mathrm{p}<0.01, * * \mathrm{p}<0.05$, and $* \mathrm{p}<0.1$. The dependent variable in Columns 1-5 is behavioral type classified based on four conditional choices in the Joy of Destruction game (JDG) and the Prisoner's Dilemma game (PDG). Subjects are classified into five mutually-exclusive types: Anti-social (always reducing other's payoff), Self-regarding (always maximizing own payoff), Pro-social (always maximizing other's payoff), Conditional cooperator (always choosing the same action as the counterpart), and Other (all other combinations of choices). GROUP indicates that the choice was made in a group of three randomly matched subjects, who had time to deliberate and reach a joint decision. The omitted category is the INDIVIDUAL condition, where choices were made in isolation. In Panel A we control for a dummy variable indicating whether the observation is from the Ugandan or the Slovak sample. 
TABLE A.8: THE EFFECT OF GROUP DECISION-MAKING ON AGGRESSIVE COMPETITIVENESS (UGANDA)

\begin{tabular}{|c|c|c|c|c|c|c|c|c|}
\hline \multirow{2}{*}{$\begin{array}{l}\text { Dependent variable } \\
\text { Sample }\end{array}$} & \multicolumn{8}{|c|}{ Behavioral types based on CG, PDG and JDG } \\
\hline & $\begin{array}{c}\text { Anti-social \& } \\
\text { Competitive } \\
(1)\end{array}$ & $\begin{array}{c}\text { Anti-social \& } \\
\text { Not_competitive } \\
(2)\end{array}$ & $\begin{array}{l}\text { Self-regarding } \\
\text { \& Competitive } \\
(3) \\
\end{array}$ & $\begin{array}{c}\text { Self-regarding \& } \\
\text { Not_competitive } \\
(4)\end{array}$ & $\begin{array}{c}\text { Pro-social \& } \\
\text { Competitive } \\
(5)\end{array}$ & $\begin{array}{c}\text { Pro-social \& } \\
\text { Not_competitive } \\
(6)\end{array}$ & $\begin{array}{c}\text { Ambiguous \& } \\
\text { Competitive } \\
(7) \\
\end{array}$ & $\begin{array}{c}\text { Ambiguous \& } \\
\text { Not_competitive } \\
(8)\end{array}$ \\
\hline GROUP & $\begin{array}{c}0.16 * * * \\
(0.03)\end{array}$ & $\begin{array}{l}-0.02 \\
(0.03)\end{array}$ & $\begin{array}{c}0.05 * * \\
(0.02)\end{array}$ & $\begin{array}{c}0.03 \\
(0.02)\end{array}$ & $\begin{array}{l}-0.03 \\
(0.02)\end{array}$ & $\begin{array}{c}-0.11 * * * \\
(0.02)\end{array}$ & $\begin{array}{l}-0.01 \\
(0.01)\end{array}$ & $\begin{array}{c}-0.07 * * * \\
(0.02)\end{array}$ \\
\hline Mean INDIVIDUAL & 0.16 & 0.23 & 0.09 & 0.09 & 0.10 & 0.20 & 0.04 & 0.09 \\
\hline Observations & 842 & 842 & 842 & 842 & 842 & 842 & 842 & 842 \\
\hline
\end{tabular}

Notes: Columns 1-8 report marginal effects from multinomial logit estimates, standard errors in parentheses. $* * *$ denotes $\mathrm{p}<0.01$, $* * \mathrm{p}<0.05$, and $* \mathrm{p}<0.1$. The dependent variable in Columns 1-8 are eight mutually exclusive behavioral types classified based on CG choices and unconditional choices in PDG and JDG. Subjects are classified as 1) Anti-social \& Competitive if they destroyed resources in both PDG and JDG and chose to enter competition in CG, as 2) Anti-social \& Not_competitive if they destroyed resources in PDG and JDG, but did not compete in CG, as 3) Self-regarding \& Competitive if they destroyed resources in PDG, but not JDG and chose to enter competition in CG, as 4) Self-regarding \& Not_competitive if they destroyed resources in PDG, but not JDG and did not compete in CG, as 5) Pro-social \& Competitive if they did not destroy resources in either PDG or JDG, but chose to enter competition in CG, as 6) Pro-social \& Not_competitive if they did not destroy resources in either PDG or JDG and did not compete in CG, as 7) Ambiguous \& Competitive if they did not destroy resources in PDG, but made a destructive choice in JDG and chose to enter competition in CG, as 8) Ambiguous \& Not competitive if they did not destroy resources in PDG, made a destructive choice in JDG and did not compete in CG. GROUP indicates that the choice was made in a group of three subjects and the ommitted category is the INDIVIDUAL condition, where choices were made in isolation. 